\title{
Mineral Resource Information Sources in the Western United States
}

Prepared in cooperation with the U.S. Bureau of Land Management, the U.S. Bureau of Mines, and the States of Alaska, Arizona,

California, Colorado, Hawaii, Idaho, Montana, Nevada, New Mexico,

Oregon, Utah, Washington, and Wyoming

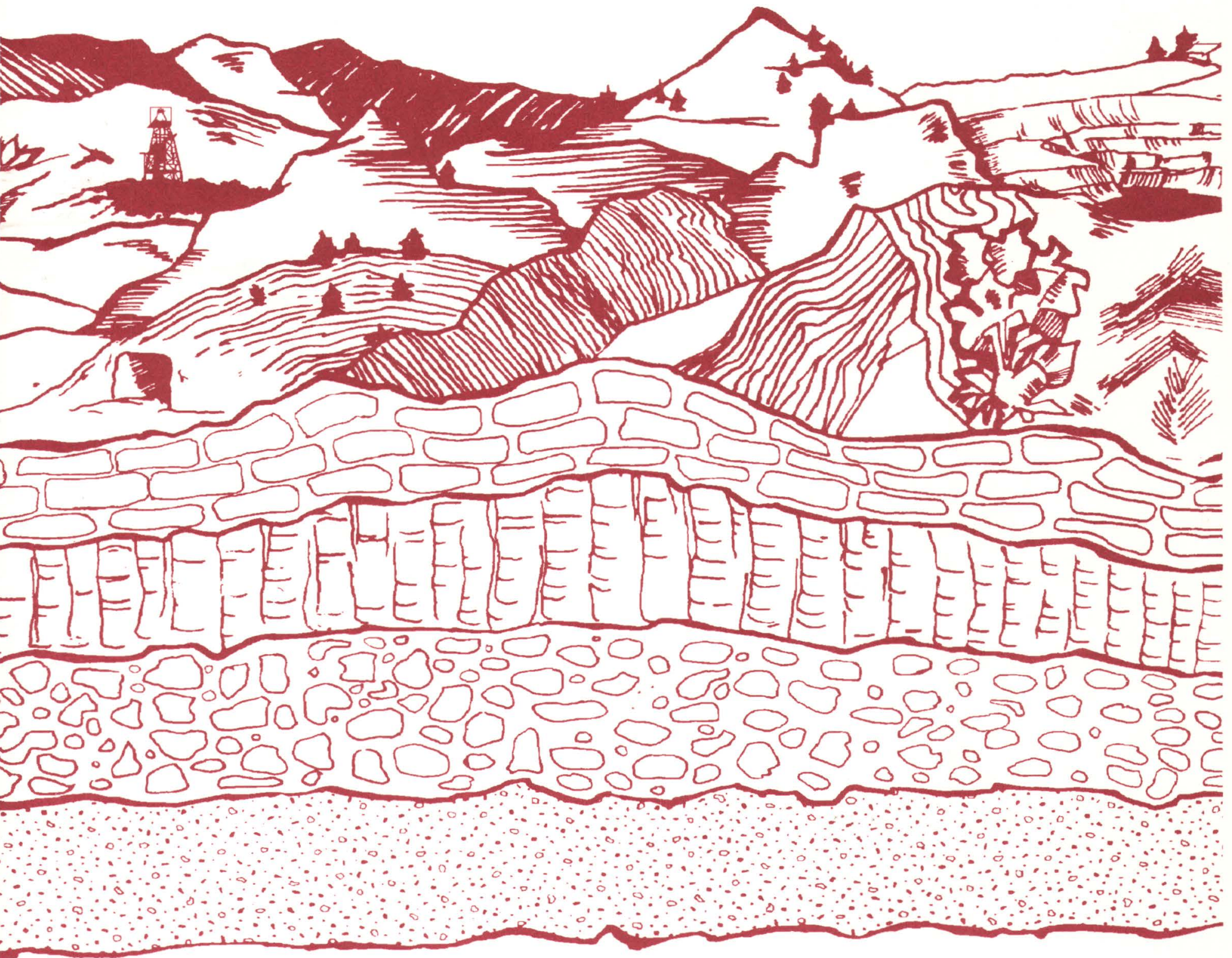

\section{U.S. GEOLOGICAL SURVEY CIRCULAR 1063}




\section{AVAILABILITY OF BOOKS AND MAPS OF THE U.S. GEOLOGICAL SURVEY}

Instructions on ordering publications of the U.S. Geological Survey, along with prices of the last offerings, are given in the current-year issues of the monthly catalog "New Publications of the U.S. Geological Survey." Prices of available U.S. Geological Survey publications released prior to the current year are listed in the most recent annual "Price and Availability List." Publications that are listed in various U.S. Geological Survey catalogs (see back inside cover) but not listed in the most recent annual "Price and Availability List" are no longer available.

Prices of reports released to the open files are given in the listing "U.S. Geological Survey Open-File Reports," updated monthly, which is for sale in microfiche from the U.S. Geological Survey, Books and Open-File Reports Section, Federal Center, Box 25425, Denver, CO 80225. Reports released through the NTIS may be obtained by writing to the National Technical Information Service, U.S. Department of Commerce, Springfield, VA 22161; please include NTIS report number with inquiry.

Order U.S. Geological Survey publications by mail or over the counter from the offices given below.

\section{BY MAIL}

\section{Books}

Professional Papers, Bulletins, Water-Supply Papers, Techniques of Water-Resources Investigations, Circulars, publications of general interest (such as leaflets, pamphlets, booklets), single copies of Earthquakes \& Volcanoes, Preliminary Determination of Epicenters, and some miscellaneous reports, including some of the foregoing series that have gone out of print at the Superintendent of Documents, are obtainable by mail from

\section{U.S. Geological Survey, Books and Open-File Reports Federal Center, Box 25425 \\ Denver, CO 80225}

Subscriptions to periodicals (Earthquakes \& Volcanoes and Preliminary Determination of Epicenters) can be obtained ONLY from the

\section{Superintendent of Documents \\ Government Printing Office \\ Washington, D.C. 20402}

(Check or money order must be payable to Superintendent of Documents.)

\section{Maps}

For maps, address mail orders to

\section{U.S. Geological Survey, Map Distribution \\ Federal Center, Box 25286 \\ Denver, CO 80225}

Residents of Alaska may order maps from

\author{
Alaska Distribution Section, U.S. Geological Survey, \\ New Federal Building - Box 12 \\ 101 Twelfth Ave., Fairbanks, AK 99701
}

\section{OVER THE COUNTER}

\section{Books}

Books of the U.S. Geological Survey are available over the counter at the following Geological Survey Public Inquiries Offices, all of which are authorized agents of the Superintendent of Documents:

- WASHINGTON, D.C.--Main Interior Bldg., 2600 corridor, 18 th and C Sts., NW.

- DENVER, Colorado--Federal Bldg., Rm. 1691961 Stout St.

- LOS ANGELES, California--Federal Bldg., Rm. 7638, 300 N. Los Angeles St.

- MENLO PARK, California--Bldg. 3 (Stop 533), Rm. 3128, 345 Middlefield Rd.

- RESTON, Virginia--503 National Center, Rm. 1C402, 12201 Sunrise Valley Dr.

- SALT LAKE CITY, Utah--Federal Bldg., Rm. 8105, 125 South State St.

- SAN FRANCISCO, California--Customhouse, Rm. 504, 555 Battery St.

- SPOKANE, Washington--U.S. Courthouse, Rm. 678, West 920 Riverside Ave..

- ANCHORAGE, Alaska--Rm. 101, 4230 University Dr.

- ANCHORAGE, Alaska--Federal Bldg, Rm. E-146, 701 C St.

\section{Maps}

Maps may be purchased over the counter at the U.S. Geological Survey offices where books are sold (all addresses in above list) and at the following Geological Survey offices:

- ROLLA, Missouri--1400 Independence Rd.

- DENVER, Colorado--Map Distribution, Bldg. 810, Federal Center

- FAIRBANKS, Alaska--New Federal Bldg., 101 Twelfth Ave. 


\section{ERRATA SHEET}

U.S. Geological Survey Circular 1063 ("Mineral Resource

Information Sources in the Western United States")

GPO Jacket 585-048/Print Order 30029

Pages 13 and 14:

The address and telephone number for the U.S. Geological Survey's Minerals Information Office in Tucson, Arizona, are incorrect. The correct address and telephone number are:

Minerals Information Office

U.S. Geological Survey

Corbett Building

340 N. 6th Ave.

Tucson, AZ 85705

$602-670-5544$

The location of this office should be on the southeast corner of 6th Avenue and 7th Street, not as shown on the map on page 14. 


\section{Mineral Resource Information Sources in the Western United States}

Edited by SUSAN M. MARCUS

Prepared in cooperation with the U.S. Bureau of Land Management, the U.S. Bureau of Mines, and the States of Alaska, Arizona, California, Colorado, Hawaii, Idaho, Montana, Nevada, New Mexico,

Oregon, Utah, Washington, and Wyoming 
U.S. DEPARTMENT OF THE INTERIOR

MANUEL LUJAN, JR., Secretary

\author{
U.S. GEOLOGICAL SURVEY \\ Dallas L. Peck, Director
}

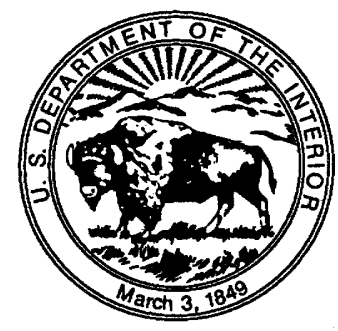

Any use of trade, product, or firm names

in this publication is for descriptive purposes only

and does not imply endorsement by the U.S. Government

UNITED STATES GOVERNMENT PRINTING OFFICE, WASHINGTON : 1991

Free on application to

Books and Open-File Reports Section

U.S. Geological Survey

Federal Center, Box 25425

Denver, CO 80225 


\section{Preface and Acknowledgments}

This report is the result of concerted efforts of people from 11 Western State agencies and 3 Federal agencies in order to improve public access to the facilities, data, and technical personnel in their organizations. No two agencies are the same, so the format of the information provided here varies slightly from one chapter to another. This report is simply an introduction to the services of the agencies; the reader is encouraged to use the telephone numbers and addresses provided here to obtain more specific information.

The U.S. Geological Survey wishes to acknowledge the cooperation of the State and Federal participants who made this report possible and who are dedicated to the belief that mineral resource information should be readily available to the public. Their flexibility and patience have made this compilation proceed smoothly. Specifically, chapters were written or assistance was provided by:

James Barker, New Mexico Bureau of Mines and Mineral Resources

Earl Bennett, Idaho Geological Survey

Richard Berg, Montana Bureau of Mines and Geology

Mark Davis, Colorado Geological Survey

Robert Gloyn, Utah Geological and Mineral Survey

Jerry Gray, Oregon Department of Geology and Mineral Industries

Dan Hausel, Geological Survey of Wyoming

Jean Juilland, U.S. Bureau of Land Management

Ralph Loyd, Division of Mines and Geology, California

Michael McKinley, U.S. Bureau of Mines

William Phillips, Washington Geology and Earth Resources Division

Becky Weimer Purkey, Nevada Bureau of Mines and Geology

John Rapp, Division of Mines and Geology, California

Bryce Tripp, Utah Geological and Mineral Survey

Patti Tuholski, U.S. Geological Survey

John W. Welty, Arizona Geological Survey

Milton Wiltse, Alaska Division Geological and Geophysical Surveys 



\section{CONTENTS}

Preface and acknowledgments III

Minerals information sources in Federal agencies 1

U.S. Bureau of Land Management 1

U.S. Bureau of Mines 4

U.S. Geological Survey 11

Minerals information sources in State agencies 15

Alaska 15

Arizona 18

California 22

Colorado 25

Hawaii 27

Idaho 28

Montana 30

Nevada 33

New Mexico 36

Oregon 40

Utah 42

Washington 46

Wyoming 49

Additional sources of minerals information $\mathbf{5 1}$

Geologic time chart 52

\section{FIGURES}

1. Role of the U.S. Bureau of Mines in the minerals cycle 4

2. Role of the U.S. Bureau of Mines in the collection and distribution of minerals information 5

3. Location of the U.S. Bureau of Mines Research and Field Operations Centers 6

4. Locations of U.S. Bureau of Mines, Offices of State Activities 9

5. Locations of U.S. Geological Survey Minerals Information Offices 14

6. Index map of Alaska, with sites referred to in text 15

7. Location of Arizona Geological Survey, Tucson, Arizona 21

8. Locations of Division of Mines and Geology offices in California 24

9. Location of Montana Bureau of Mines and Geology, Butte, Montana 31

10. Location of Nevada Bureau of Mines and Geology, and related offices, Reno, Nevada 35

11. Location of New Mexico Bureau of Mines and Mineral Resources and selected public facilities, Socorro, New Mexico 38

12. State and Federal minerals agencies in Salt Lake City, Utah 44

13. Index map of Washington, with sites referred to in text 46

14. Location of Geological Survey of Wyoming, Laramie, Wyoming $\mathbf{5 0}$ 



\section{Mineral Resource Information Sources in the Western United States}

\author{
Edited by Susan M. Marcus
}

\section{MINERALS INFORMATION SOURCES IN FEDERAL AGENCIES}

\section{U.S. Bureau of Land Management}

By Jean Juilland

The Bureau of Land Management (BLM) is part of the U.S. Department of the Interior, and its purview is the public domain lands and their respective resources. It manages the surface and subsurface (energy and minerals) estate of 272 million acres (about one-eighth of the Nation) and another 300 million acres of subsurface estate only, the surface of which is owned and (or) administered by private interests, State, or other Federal agencies (for example, U.S. Forest Service). Most of the lands managed by the BLM are located in 11 Western States, including Alaska, but small parcels are scattered across the Eastern United States.

The public lands managed by the BLM contain diverse and substantial amounts of energy and mineral resources, including coal, oil and gas, mineral materials, metallic minerals, and many others. In accordance with the laws of the United States, the BLM supports and facilitates the exploration, development, and extraction of energy and mineral resources in an environmentally sound manner. It has both regulatory and management responsibilities. To accomplish its multiple-use/multipleresources mandate, it needs to know what and where the present energy and mineral activities are, and also what the potential for occurrence of yet undiscovered mineral deposits on public lands might be.

For these purposes, the BLM gathers geology, energy, and mineral (GEM) resources data. Most of these data exist already in published and unpublished reports and data bases. Occasionally, and for relatively small ar-

Manuscript approved for publication, January 18, 1991. eas (for example, mining claims evaluated for patent), the BLM generates new data.

The BLM has considerable derived (thematic) information which helps in its multiple-use management of the public lands. For example, there may be maps showing the potential for the occurrence of energy and mineral resources for a given Resource Area. The land is classified as having high, moderate, and (or) low potential, and each of these classes is assigned a level of certainty depending on the quantity and quality of the data on which the classification was made.

All these data are not nationally centralized within one BLM office, but some are centralized within a State, and (or) District. Some of these data are in computer data bases, and others are in different types of manual files and (or) plats and maps. Currently, the Bureau of Land Management is developing a Land Information System (LIS) which will consist of three key parts:

1. The automated Geographic Coordinate Data Base (GCDB) is based on data from the National Public Land Survey System. The GCDB system provides the ability to link records and resources data to legal descriptions of land parcels.

2. The Automated Land and Minerals Records System (ALMRS) provides information about ownership status, special designation (for example, wilderness description), and use authorization such as mineral leases, mining claims, and road and pipeline rights-of-way. These data are typically represented on master title plats.

3. The Automated Resource Data (ARD) represents information about resources, for example, wildlife habitat, soil classification, vegetation, and so forth, and GEM resources.

At this time (1991) only portions of this system are functional. It is expected that the LIS will be fully implemented early in the 1990's.

All of the data which the BLM has, whether in manual files or computer data bases, can be accessed in the appropriate BLM State offices and (or) District or Resource Area offices. A list of BLM State offices follows. 


\section{Mineral Information Facts at a Glance- U.S. Bureau of Land Management}

The following information materials are available free, unless otherwise noted, from the Bureau of Land Management offices:

-"Minerals for America,"-A brochure of general information about solid leasable minerals, fluid leasable minerals, locatable minerals and mineral materials.

- Mining Claims.-Brochures/pamphlets on how to stake and patent a mining claim on Federal lands.

- Federal Regulations.-Statutes for recording, maintaining, and operating mining claims on onshore public lands (that is, Federal lands administered by the Bureau of Land Management).

- "Onshore Oil and Gas Leasing System."-A brochure providing general information on leasing onshore Federal lands for oil and gas; what Federal lands are available; who qualifies; types of leases; lease terms and conditions; bonding, rentals, and royalties, and so forth.

- Resource Management Plans (RMPs) and Environmental Impact Statements (EIS's).-At respective State offices, District offices, or Resource Area offices, one can find the RMP and EIS for the management of the public lands and resources within the respective areas.

-Listings of Mining Claims.-At respective BLM State offices, District offices, or Resource Area offices, one can examine a microfiche listing of mining claims within the respective area. Mining claims are listed by: geographic location (in other words, township, and range); claim owner's name; name of claim; and serial number (the latter is the most complete). The microfiche listing is updated quarterly, and it can also be purchased from the Service Center in Denver, Colorado.

-Energy and Mineral Resources Data.-At respective BLM State offices, District offices, or Resource Area offices, one can find many kinds of resource data, including energy and mineral resources data which were used in preparation of Resource Management Plans (RMPs), Environmental Impact Statements (EIS's), land exchanges, and so forth. These data may be examined in the respective BLM office; depending on quantity and format, a nominal charge might apply for obtaining a copy of these data. Proprietary data are not available to the public.

- Maps.-Surface and mineral estate management maps are available for purchase at BLM State, District, or Resource Area offices (except for Alaska). These maps show federally administered surface by agency, by State and private party, and by States, Federal and private subsurface (mineral) ownership. Scale 1:100,000, or approximately $1 \mathrm{in} .=4,167 \mathrm{ft}$. These maps can be purchased also from some U.S. Geological Survey offices.

- Master Title Plats.-At respective BLM State,
District, or Resource Area offices, one can examine microfiche which show the official Federal agency that manages the respective land, the mineral leases, rightsof-way, and other surface and subsurface (mineral) rights, and land-use designation. These Master Title Plats cover one township of land and may be copied for a nominal fee.

- Mineral Survey Maps.-Land and mineral survey maps and the respective survey field notes can be examined in the respective BLM office. They can be viewed on microfiche and copies may be purchased for a nominal fee.

\section{U.S. Department of the Interior \\ Bureau of Land Management State Offices}

Headquarters

U.S. Department of the Interior

U.S. Bureau of Land Management

18th \& C Streets, NW.

Washington, D.C. 20240

(202) $343-5717$

Alaska

U.S. Bureau of Land Management

Federal Building

222 West 7th Avenue, \#13

Anchorage, AK 99513-7599

(907) 271-5555

Arizona

U.S. Bureau of Land Management

3707 North 7th Street

P.O. Box 16563

Phoenix, AZ 85011

(602) 241-5504

California

U.S. Bureau of Land Management

Federal Building

2800 Cottage Way, E-2841

Sacramento, CA 95825-1889

(916) $978-4746$

Colorado

U.S. Bureau of Land Management

2850 Youngfield Street

Lakewood, CO 80215

(303) $236-1700$

Eastem States ${ }^{1}$

U.S. Bureau of Land Management

350 South Pickett Street

Alexandria, VA 22304

(703) 461-1369

Jurisdiction over all States bordering the west bank of the Mississippi River and also those States east of the river. 
Idaho

U.S. Bureau of Land Management 3380 Americana Terrace

Boise, ID 83706

(208) 334-1771

Montana ${ }^{2}$

U.S. Bureau of Land Management

222 North 32nd Street

P.O. Box 36800

Billings, MT 59107

(406) 255-2913

Nevada

U.S. Bureau of Land Management

850 Harvard Way

P.O. Box 12000

Reno, NV 89520

(702) $785-6590$

New Mexico ${ }^{3}$

U.S. Bureau of Land Management Joseph M. Montoya Federal Bldg.

South Federal Place

P.O. Box 1449

Santa Fe, NM 87504-1449

(505) $988-6316$
Oregon

U.S. Bureau of Land Management 825 NE. Multnomah Street

P.O. Box 2965

Portland, OR 97208

(503) 231-6277

Utah

U.S. Bureau of Land Management 324 South State Street, Suite 301

Salt Lake City, UT 84111-2303

(801) 539-4019

Wyoming ${ }^{5}$

U.S. Bureau of Land Management

2515 Warren Avenue

P.O. Box 1828

Cheyenne, WY 82003

(307) $772-211$

Service Center - Denver, Colorado

U.S. Bureau of Land Management Denver Federal Center, Bldg. 50

Denver, CO 80225

(303) 236-8583
${ }^{2} J u r i s d i c t i o n$ over North and South Dakota as well as Montana.

${ }^{3}$ Jurisdiction over Oklahoma and Texas as well as New Mexico.
${ }^{4} J u r i s d i c t i o n$ over the State of Washington as well as Oregon. 5Jurisdiction over Kansas and Nebraska as well as Wyoming. 


\section{U.S. Bureau of Mines}

By Michael McKinley

The U.S. Bureau of Mines, as mandated by a series of Public Laws commencing with the Organic Act of 1910 , is charged with the collection, analysis, and dissemination of minerals information. This effort is done in close coordination with industry, academia, and Federal and State agencies. The U.S. Bureau of Mines and the U.S. Geological Survey have especially enjoyed a close working relationship over the years. The Bureau's information responsibilities with respect to the mineral cycle are portrayed in figure 1 .

Experts at the U.S. Bureau of Mines Information and Analysis Directorate collect and interpret data concerning mineral production, consumption, and trade both in the United States and worldwide. These Bureau experts also perform assessments on the worldwide availability of minerals and assess identified minerals on Federal lands. Comprehensive analyses are also made on the impact of government policies, economic conditions, and political events on the health and competitiveness of the U.S. mineral industry in general and on the Nation's mineral supplies. Of particular concern are the competitiveness of the domestic minerals industries and the availability of strategic and critical materials essential to national security. It is important to remember that minerals create the wealth upon which economic prosperity and defense preparedness rest.

The U.S. Bureau of Mines collects data on over 100 mineral commodities from 168 countries. Bureau mineral commodity specialists are assigned to handle specific minerals and mineral materials according to their individual areas of expertise. State activity specialists collect information about minerals from U.S. companies operating mines and mineral processing plants. Country specialists obtain data from foreign governments, U.S. embassies, and international publications and visit mines overseas to monitor worldwide mineral production and consumption and the economic and political events that affect mining. The Bureau's worldwide mineral information network is delineated in figure 2.

Besides the wealth of information produced by the Information and Analysis Program, there is another entire spectrum of interests served by the Bureau's Research Program. This program produces, for example, information concerning the Bureau's quest for technology that will help the U.S. minerals industry develop necessary new and more efficient mining and mineral processing methods. Parts of the research program concentrate on developing new technology to improve health and safety of miners and to protect the environment against adverse effects of mining. Another aspect of this program is focused on materials research. Materials researchers strive to increase conservation of resources by developing longer lasting materials; to utilize our domestic resources more effectively in producing new, high-technology materials; and to reduce our dependency on imported raw materials. For further information on the Bureau Research Program, contact the Minerals Information Office in Washington, D.C., or the Office of Public Information, U.S. Bureau of Mines, $2401 \mathrm{E}$ Street, NW., Washington, D.C. 20241, telephone: (202) 634-1001 (also see figure 3).

A brief synopsis of principal Bureau publications and data bases follows:

"Minerals Yearbook."-The "Minerals Yearbook" provides the definitive historical record for mineral statistics used by government and industry in assessing U.S. mineral supply and the characteristics of U.S. mineral demand. It also provides worldwide information on the production and consumption of minerals. Beginning

GEOLOGICAL SURVEY

BUREAU OF MINES

COMMERCE, LABOR, DEFENSE AND OTHERS

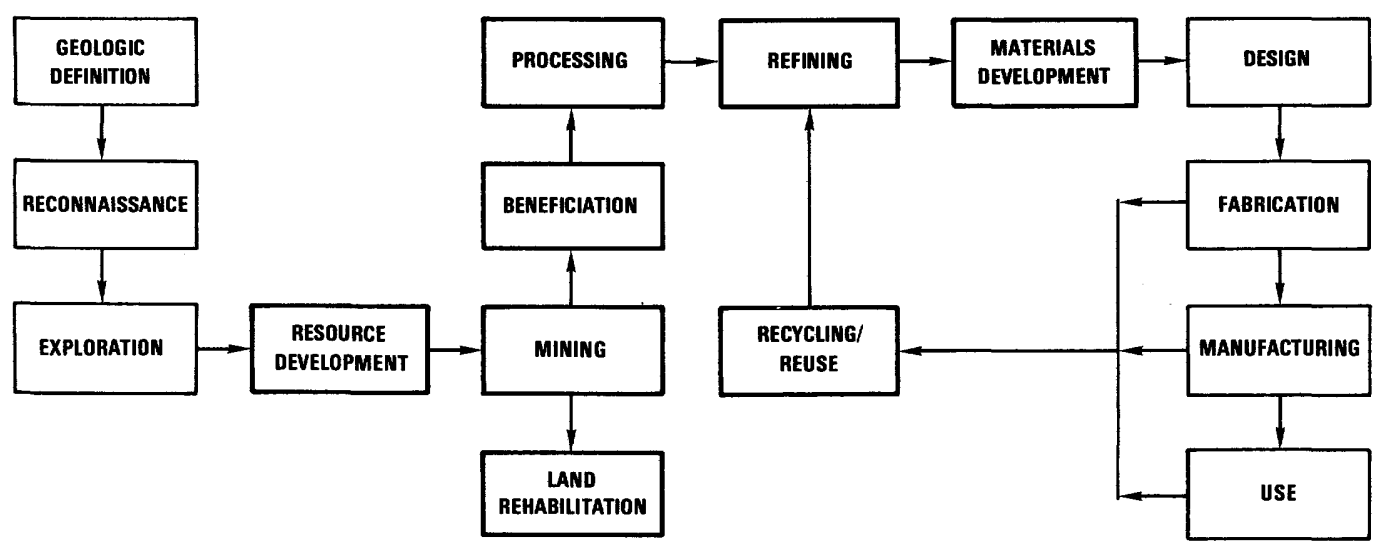

Figure 1. Role of the U.S. Bureau of Mines in the minerals cycle. 


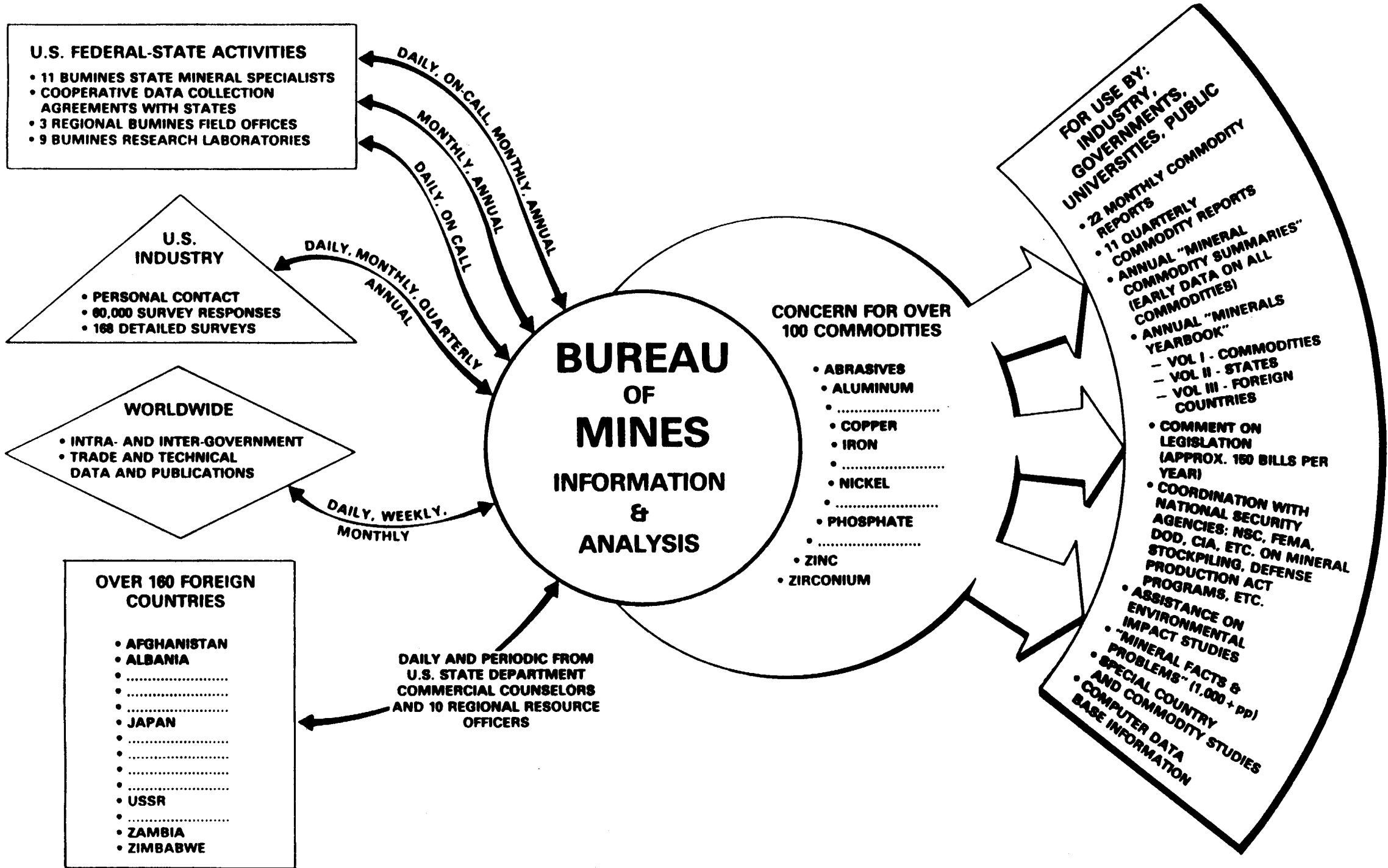

Figure 2. Role of the U.S. Bureau of Mines in the collection and distribution of minerals information. 


\section{BUREAU OF MINES FIELD FACILITIES}

(The Bureau of Mines also maintains staff expertise for mineral

activities in all $\mathbf{5 0}$ states in the U.S. and $\mathbf{1 6 8}$ foreign countries

and for some 600 minerals and mineral - related materials).

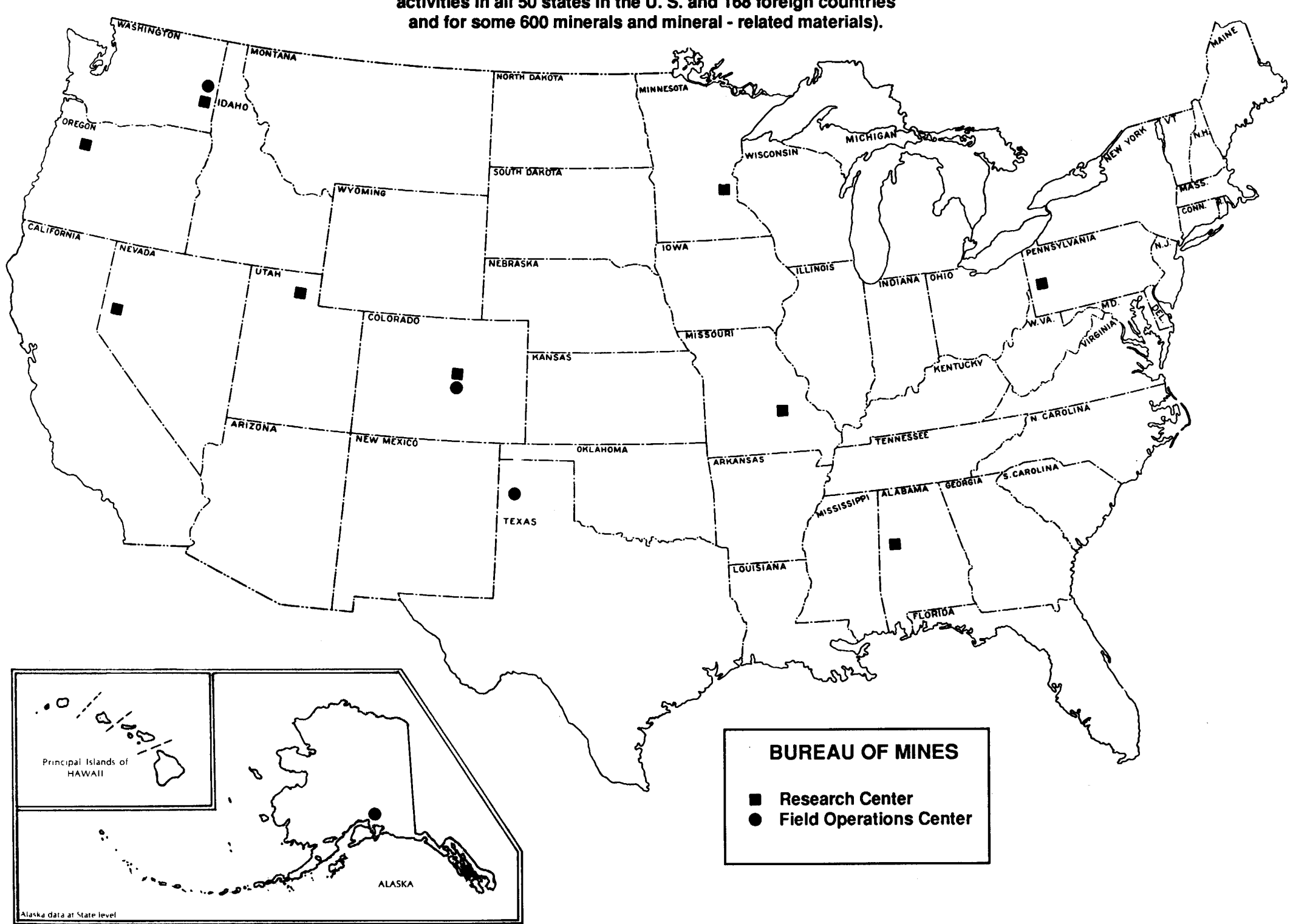

Figure 3. Location of the U.S. Bureau of Mines Research and Field Operations Centers. 
with the 1988 edition, the "Minerals Yearbook" format has been enlarged to an $81 / 2 \times 11$ in. size with emphasis on the individual chapters rather than the bound volume. Each chapter is published as an individual report with its own cover.

- Minerals Yearbook Volume I (Metals and Minerals)."- Starting with the 1989 edition, the content of Volume I of the Yearbook will be expanded to include information on industry structure, technology, supply/demand analysis, economic factors, and forecasts of U.S. and world demand for individual commodities. Much of this information had previously been published only every 5 years in "Mineral Facts and Problems," which will be eliminated as a separate publication. Information is available commencing in July of the following year with final softback reports available in December. The hardbound volume is not available until the following January, or about 13 months after year end. Individual softback commodity chapters are free. The hardbound volume is a for-sale publication.

- "Minerals Yearbook Volume II (Area Reports: Domestic)."-This information is organized by State. Information initially available commencing in November of the following year with final softback reports available next January. The hardbound volume is not available until the following May, or about 17 months after year end. Individual softback State chapters are free. The hardbound volume is a for-sale publication.

"Minerals Yearbook - International Review," This information is organized by country and region. Beginning with the 1989 edition, the content of Volume III will be expanded to provide more comprehensive information. This expansion will include the mineral supply and trade position of each country, details on mineral development and foreign investment policies, structure of the mining industry, infrastructure, and industry outlook, and a map locating major mines and facilities. Much of this information had previously been published on a 5year cycle in the "Minerals Perspectives" regional reference book series. The expanded yearbook format will be presented in six bound sections: Europe and the USSR; Africa; the Middle East; Latin America and Canada; Far East and Australia; and Minerals in the World Economy. The hardbound sections for the 1989 edition will be published next March or about 15 months after year end. Subsequent editions will be published the following December or within 12 months of year end. The hardbound sections will be for-sale publications.

" "Mineral Industry Surveys."-The surveys provide periodic data designed to give timely statistical information on production, distribution, stocks, and consumption of significant mineral commodities. A total of about 400 surveys are issued throughout the year, on a monthly, quarterly, and annual basis. Electronic publication methods are also being initiated on an experimental basis for selected commodities. Starting in 1989 , sample quarterly surveys of crushed stone and of sand and gravel production were conducted by telephone and reports were published within 45 days after the close of the quarter. "Mineral Industry Surveys" are free publications.

"Mineral Commodity Summaries."-This annual report published each January provides estimates on production, consumption, trade, recycling, substitution, reserves, resources, and other relevant information on mineral commodities. More definitive data are published later in the "Minerals Yearbook." The report published in 1990 included, for the first time, a section on International Events and also a Minerals Outlook section for major industry sectors. "Mineral Commodity Summaries" is a free publication.

"State Mineral Summaries."-This is a companion publication to "Mineral Commodity Summaries." It contains reports for the 50 States and Puerto Rico. It is published each February for the preceding year. "State Mineral Summaries" is a free publication.

"Mineral Perspective Series."-This series focuses on in-depth studies of selected countries, analyzing the technical, policy, and economic factors affecting their mineral industries. As mentioned previously, a prior format used in the series was a regional reference book with information that will now be included in Volume III of the "Minerals Yearbook." Studies on Namibia, Zaire, and Zimbabwe have been published and will be followed by studies on Guinea and Mexico. Reports are produced intermittently and are for-sale publications.

" Mineral Issues Series."-These are detail reports on selected commodities that involve extensive native language research and analysis of key industrial sectors of major mineral producing countries. Detailed assessments of the chromium, manganese, tungsten, and copper industries of the USSR have been published. Additional studies on the nickel-cobalt and lead-zinc industries of the USSR and on the Chinese iron and steel industry are underway. Reports are produced intermittently and are for-sale publications.

"Compendium of Historical Statistics."-In response to requests by users of Bureau statistics, a new publication will be prepared in 1992 to provide historical data for some of the statistical series published in the "Minerals Yearbook." Previously, a historical series could be compiled by the user only by having access to a complete set of yearbooks. Each yearbook carried data for only 3 to 5 years. The new publication contains longterm data for such series as production and consumption of individual commodities, and value of mineral production by State.

"Minerals Today" (formerly known as "Minerals and Materials").-This is a bimonthly magazine that provides a snapshot of major activities within the mineral industry and the Bureau of Mines. It is currently being 
revised and serves as focal point for analysis and debate on mineral/material policy issues. This is a for-sale publication.

- Automated Minerals Information System (AMIS).-This large data base contains information about specific mineral commodities. It supports the Bureau's publication efforts previously described. The computerized portion of AMIS runs on the U.S. Geological Survey's mainframe computer in Reston, Va., and currently uses the Model 204 data base language; incorporates integration of microcomputers to enable some commodity surveys to be processed on micros and uploaded to the mainframe. Information can also be downloaded to micros to facilitate analyses by Bureau specialists. The AMIS is not currently available for public access due to its proprietary nature. However, the $\mathrm{Bu}-$ reau has initiated an electronic bulletin board for limited access to nonproprietary data and has plans for expanding this function in the future.

- Minerals Availability System (MAS).-MAS is part of the Minerals Availability program which assesses supplies of minerals considered essential to the U.S. industrial base. Major program activities include identifying the most important mineral operations in the world; evaluating their mineral reserves, resources, and production costs; and estimating the availability of these minerals to the United States. Basic elements of the Minerals Availability program include the Minerals Availability System (MAS), a computerized system of site-specific geological and engineering-cost information, economic analyses of individual mineral operations, and commodity availability and supply appraisals. Data on over 3,000 of the world's principal mines and mineral processing plants are contained in the MAS data base. While data and analytic results from commodity and policy studies are published in aggregate form, certain individual property information, for example, reserve and cost information, is not available to the public for economic competitiveness reasons. A fully publicly accessible data base, the Mineral Industry Location System (MILS), contains location, commodity, geology, reference information, and so forth, on over 200,000 U.S. mineral deposits and occurrences. This information is made available to the public via map overlays and computer printouts at cost.

-Mineral Land Assessments (MLA).-MLA is part of the Bureau of Mines' Land Assessment program that provides comprehensive mineral resource information used in land management decisions by the Congress and Federal land management agencies. It is also the basis for decisions which would expand the domestic supply of important mineral resources, primarily strategic and critical minerals. Much of this work is done in cooperation with the U.S. Geological Survey and includes mineral studies of lands administered by U.S. Forest
Service, U.S. Bureau of Indian Affairs, and U.S. Bureau of Land Management; mining district studies in Alaska; various site-specific studies; and environment-related studies. Data are published as either U.S. Geological Survey bulletins, and miscellaneous field studies, or U.S. Bureau of Mines open-file reports.

"Research (year)." - This publication is an annual summary of U.S. Bureau of Mines programs with emphasis on recent research accomplishments. Published in January of the following year. This is a for-sale publication.

"Mineral Position of the United States - (year)."This is the annual report of the Secretary of the Interior under the Mining and Minerals Policy Act of 1970. Published in July of the following year. Free publication.

\section{Mineral Information Facts at a Glance- U.S. Bureau of Mines}

General inquiries:

\author{
Office of Public Information \\ U.S. Bureau of Mines \\ 2401 E Street, NW. MS-1040 \\ Washington, D.C. 20241-0001 \\ (202) 634-1001 \\ Office hours: 7:45 a.m. to 4:15 p.m.-Monday through Friday
}

Inquiries concerning specific commodities:

Chief, Division of Mineral Commodities

U.S. Bureau of Mines

2401 E Street, NW. MS-5206

Washington, D.C. 20241-0001

(202) 634-1187

Office hours: 7:45 a.m. to 4:15 p.m.-Monday through Friday

Inquiries concerning State activities:

Chief, Office of State Activities

U.S. Bureau of Mines

2401 E Street, NW. MS-9700

Washington, D.C. 20241-0001

(202) 634-1107

Office hours: 7:45 a.m. to 4:15 p.m.-Monday through Friday

See figure 4 for regional locations

Inquiries concerning international minerals:

Chief, Division of Intemational Minerals

U.S. Bureau of Mines

2401 E Street, NW. MS-5205

Washington, D.C. 20241-0001

(202) 632-8970

Office hours: 7:45 a.m. to 4:15 p.m.-Monday through Friday

Inquiries concerning minerals availability:

Chief, Branch of Minerals Availability

U.S. Bureau of Mines

2401 E Street, NW. MS-5202 


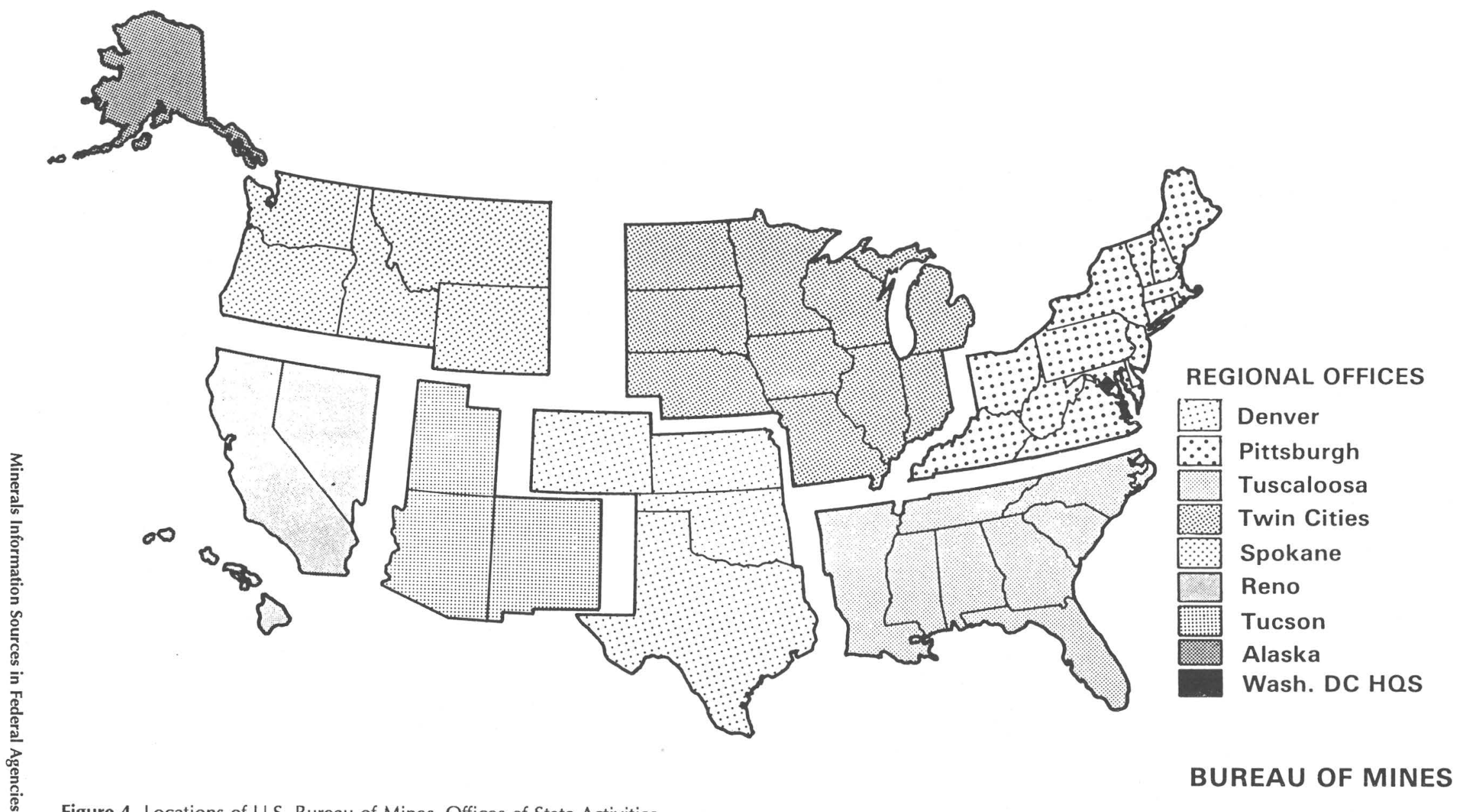

Figure 4. Locations of U.S. Bureau of Mines, Offices of State Activities. 
Washington, D.C. 20241-0001

(202) 634-1144

Office hours: 7:45 a.m. to 4:15 p.m.-Monday through Friday

Inquiries concerning mineral land assessments:

Chief, Branch of Mineral Land Assessment

U.S. Bureau of Mines

2401 E Street, NW. MS-5202

Washington, D.C. 20241-0001

(202) 634-4744

Office hours: 7:45 a.m. to 4:15 p.m.-Monday through Friday

Publications and sales:

\section{Sales Publications:}

Sales publication purchases may be made by check or money order payable to the Superintendent, charged to a deposit account at the Government Printing Office, or charged on a VISA or MasterCard credit card. Address:

Superintendent of Documents

U.S. Government Printing Office

Washington, D.C. 20402

or call (202)783-3238.

An additional one-fourth of the current selling price of publication(s) ordered should be added on orders going to countries other than the United States or its possessions. Postage stamps and foreign money are not acceptable. When ordering publications by mail, please be sure to include your zip code. There is a minimum charge of $\$ 1$ for each mail order.

Sales publications include hard bound volumes of the "Minerals Yearbook," "Mineral Perspectives," "Research (year)," "Minerals Issues," and "Minerals Today."

\section{Free Publications:}

Requests for free publications should be made to:

Publication Distribution

Bureau of Mines

Cochrans Mill Rd., P.O. Box 18070

Pittsburgh, PA 15236

or call (412)892-4338
Because of the limited editions, only 1 copy of any publication can be sent to the person applying and a maximum of 10 titles to any applicant. Applicants should request only those publications actually needed. Please enclose a self-addressed label.

Free publications include individual "Minerals Yearbook" chapters, "Mineral Industry Surveys," "Mineral Commodity Summaries," "State Mineral Summaries," monthly announcements of "New Publications-Bureau of Mines, Mineral Position of the United States-(year)". Many "Reports of Investigation" and "Information Circulars" are also free.

The following referenced publication is scheduled to be printed in 1992 - "Compendium of Historical Statistics." Address inquiries to the Bureau's Publication Distribution address previously mentioned.

\section{Open File Reports-NTIS:}

An open file report is an unpublished Bureau of Mines report that has been made available as reference material. Any open file report may be inspected during working hours at various Bureau locations but may not be removed. The Natural Resources Library, U.S. Department of the Interior, Washington, D.C. 20240, can usually supply copies on interlibrary loan. For further information, contact the library, (202)208-5815.

If a report number is prefixed with $\mathrm{PB}$, the report may be purchased, by check or money order, payable to the National Technical Information Service, charged to a deposit account at NTIS, or charged on a VISA, MasterCard, or American Express credit card, from:

National Technical Information Service
U.S. Department of Commerce

Springfield, VA 22161

or call (703)487-4650. Please order by numbers given.

Microfiche copies are $\$ 6.95$ (domestic order) and $\$ 13.90$ (foreign order). Paper copies are available at the prices indicated; double the price for foreign orders except those going to Canada or Mexico. To each domestic order, add $\$ 3$ per order (not per item) for handling; for foreign orders, including those to Canada and Mexico, add \$4 per order. Note that additional addresses on orders are each charged the handling charge. Rush and express services are available at an additional charge. 


\section{U.S. Geological Survey}

By Susan M. Marcus

The U.S. Geological Survey is the Federal agency that is responsible for a national perspective on geologic aspects of mineral resources. Mineral resource studies, both domestic and foreign, are managed through three major programs within the U.S. Geological Survey's Office of Mineral Resources. The three programs are: the National Mineral Resource Assessment Program, the Strategic and Critical Minerals Program, and the Development of Assessment Techniques Program.

National Mineral Resources Assessment Program (NAMRAP).-This program oversees mineral resource studies of national forests, and areas that may become wilderness, as well as other studies on public lands. These studies include geochemical and geophysical surveys, geologic mapping, and investigations of mineralized areas and conclude with evaluations of the likelihood of undiscovered mineral resources. The scope of the work is regional, rather than specific to mineralized sites. Results are made available to the public as U.S. Geological Survey bulletins, open-file reports, and maps. The Conterminous United States Mineral Assessment Program (CUSMAP) and the Alaska Mineral Resource Assessment Program (AMRAP) are components of NAMRAP that involve interdisciplinary studies of the potential for undiscovered mineral resources on areas throughout the country. Data and mineral resource assessments from CUSMAP and AMRAP are often published at 1:250,000.

Strategic and Critical Minerals Program (SCM).This program seeks to enhance the understanding of the geologic distribution of deposits of strategic and critical mineral resources. Although the emphasis of the program is on strategic and critical minerals, deposits of other mineral commodities are studied as well. By conducting research to determine how deposits form and why they occur in specific locations, geologists improve their ability to predict the occurrence of undiscovered mineral resources. The scope of the work in this program is usually specific to mineralized sites, with extrapolation carried to areas where mineralization is not known. Research conclusions are usually published as U.S. Geological Survey professional papers, bulletins, maps, and journal articles.

Development of Assessment Techniques Program (DAT).-This program investigates new geochemical, geophysical, and geologic methods that have the potential to improve the ability to predict the formation and existence of undiscovered mineral resources. New equipment and analytical methods are developed, and existing data are reinterpreted. The scope of the studies in this program varies from laboratory research to testing techniques or ideas in the field. Results are usually published as U.S. Geological Survey professional papers, bulletins, and journal articles.

The U.S. Geological Survey has established four Minerals Information Offices to help the public gain access to the large volume of the agency's mineral resource data. The offices, listed below, provide information from several digital data bases, as well as from published and unpublished reference materials. Responses are tailored to the needs of the client and may consist, for example, of lists of sites where specific mineral commodities are found, or information about the geologic setting for a particular commodity, or a referral to a U.S. Geological Survey scientist working on a mineral resource issue. The Minerals Information Office in Washington, D.C., is a cooperative endeavor with the U.S. Bureau of Mines. The offices in Tucson, Ariz., and Reno, Nev., operate in close cooperation with the Arizona Geological Survey and the Nevada Bureau of Mines and Geology, respectively. The office in Spokane, Wa., is operated independently by the U.S. Geological Survey.

There are several U.S. Geological Survey computerized data bases of interest to mineral resource data users:

- Mineral Resources Data System.-The Mineral Resources Data System (MRDS), formerly known as CRIB, is the major repository of digital mineral resource information in the U.S. Geological Survey. The Mineral Resource Data System consists of over 90,000 records of mineralized sites throughout the world. The records contain information on the location and commodities present at the sites along with a variety of geologic information, including host rock, age of mineralization, and type of mineralization. Plots and listings of the sites can be printed, based on primary commodity, location, or a wide choice of variables, depending on the user's needs. This data base is available for interactive use at the Minerals Information Offices.

- Mineral Resource Specialists.-This data base includes the names, addresses, and telephone numbers of the U.S. Geological Survey researchers who have particular knowledge about the genesis, characteristics, and distribution of specific mineral resources (for example, tin, gold, or chromium). The file also contains major bibliographic references for each mineral resource. This data base is available for interactive use at the Minerals Information Offices.

- National Mineral Resources Assessment Program.-The status and results of projects under the Conterminous United States Mineral Assessment Program and the Alaska Mineral Resource Assessment Program are given in this file. It is linked to graphic displays showing the location of each project. This data base is available for interactive use at the Minerals Information Offices. 
- National Geochemical Data Base. - This data base contains information about the location, site geology, and analytical results of samples analyzed by the geochemical laboratories of the U.S. Geological Survey. It consists of two parts-the Rock Analysis Storage System (RASS) and Pluto, which will be merged in the future. Access to geochemical data is available, by referral, from the Minerals Information Offices. There may be fees for some data sets.

- Geophysical Data-A variety of gravity, aeromagnetic, satellite, and other digital data sets are available from the U.S. Geological Survey and, by referral, from other Federal agencies. Costs of data depend on the data source, format required, and other specifications. Contact the Minerals Information Offices for more information about access to and the availability of geophysical data.

- National Uranium Reconnaissance Evaluation.The National Uranium Reconnaissance Evaluation (NURE) was a program conducted by the U.S. Department of Energy from 1974 to 1983. Stream sediment and heavy mineral concentrate geochemical samples were taken throughout the United States, along with other types of samples in selected areas. Reconnaissance magnetic and radiometric surveys were also made. Digital and hard copy data are available through the U.S. Geological Survey. Contact the Minerals Information Offices for more information. There are fees for most data.

-Earth Science Data Directory.-The Earth Science Data Directory is a digital data base that contains listings of about 1,500 digital and nondigital data bases related to geology, energy, minerals, water, land, plant, and other resources. It is accessible from other computers via a modem. Users and contributors may contact: ESDD Project Manager, U.S. Geological Survey, 801 National Center, Reston, Virginia 22092 or telephone (703)6487112.

Selected publications of the U.S. Geological Survey useful to those interested in minerals and mineral resources include:

-"Mineral Deposit Models" (Bulletin 1693).-This book explains the geologic and geochemical characteristics of the occurrence of more than 39 different types of mineral deposits It also includes tonnage and grade models for most deposit types. Cost: $\$ 19.00$

- Mineral Resource Assessments.-These products of the National Mineral Resource Assessment Program describe the potential for undiscovered mineral resources in various tracts of lands in the United States and certain foreign countries. Most assessments are published as bulletins, sometimes with a summary published as a circular and supporting data available as open-file reports. Many reports contain contributions on identified (known) mineral resources by the U.S. Bureau of Mines. Contact the Minerals Information Offices for information about specific areas or reports. Cost: approximately $\$ 2$ to $\$ 10$.

-Data Bases and Systems of the U.S. Geological Survey. 1983" (Circular 817).-This free publication lists digital data bases maintained by the U.S. Geological Survey and certain data bases maintained by the U.S. Bureau of Land Management and the U.S. Minerals Management Service. Brief descriptions of the data bases are given along with addresses and phone numbers of people to contact. The circular is available from the Books and Open-File Reports Section (see following address).

-General Interest Publications.-Free pamphlets are available on a variety of topics, including gold and lithium, and general geologic subjects such as geologic time and earthquakes. Individual copies are available upon request from the Books and Open-File Reports Section (see following address).

" "Guide to Obtaining USGS Information" (Circular 900).-This free booklet is available from the Books and Open-File Reports Section (see following address). It gives national and regional sources for various types of U.S. Geological Survey data.

-List of Publications-The U.S. Geological Survey prints a monthly list of its publications. Subscription to this list is free, and is available from: U.S. Geological Survey, 582 National Center, Reston, Virginia 22092.

The U.S. Geological Survey also provides the following opportunity for sharing mineral resource information:

-McKelvey Forum.-The U.S. Geological Survey sponsors an annual public symposium on the agency's energy and minerals research. The meeting, known as the McKelvey Forum, focuses on energy or mineral resources in alternate years. Papers and poster displays present the latest work of the U.S. Geological Survey on these topics. Contact the Minerals Information Offices for more information.

In addition to the Minerals Information Offices, there are sources for other information within the U.S. Geological Survey. These sources, specifically the Earth Science Information Centers and the Geologic Inquiries Group, can be accessed directly or by referral from the Minerals Information Offices.

\section{Mineral Information Facts at a Glance- U.S. Geological Survey}

General mineral resource inquiries:

Main Office

Minerals Information Office

Main Interior Bldg., Room 2647

18 th \& C Streets, NW.

Washington, D.C. 20240 
(202) $343-5512$

Office hours: 8:15 a.m. to 3:45 p.m.-Monday through Friday

\section{Branch Offices}

Minerals Information Office

U.S. Geological Survey

845 North Park Avenue

Tucson, AZ 85719

(602) 882-4795, ext. 21

Office hours: 8:00 a.m. to 4:00 p.m.-Monday, Tuesday, Thursday, Friday

Minerals Information Office

U.S. Geological Survey

c/o Mackay School of Mines

Scrugham Engineering Mines Bldg., Rm. 313A

University of Nevada, Reno

Reno, NV 89557-0047

(702) 784-5552

Office hours: 9:00 a.m. to 4:00 p.m.-Monday through Friday

Minerals Information Office

U.S. Geological Survey

Room 651, U.S. Courthouse Bldg.

West 920 Riverside Avenue

Spokane, WA 99201

(509) 353-2649

Office hours: 9:00 a.m. to 4:00 p.m.-Monday through Friday

(see fig. 5 for location)

\section{Formats Available:}

Digital and nondigital. Most digital data are on Macintosh hardware. Plots, graphs, lists, and so forth constructed to respond to individual requests.
Cost:

No charge for most information. At-cost charges for complex computer searches or complex plots.

How to Order Information:

Telephone, write, or visit the offices listed above.

Information Available:

- Textual and locational data on mineralized sites throughout the world

-Data on results of and references to U.S. Geological Survey mineral resource assessments

-Access to U.S. Geological Survey mineral resource commodity specialists and other technical specialists

-Referrals to State and Federal minerals and leasing personnel

Publications List:

U.S. Geological Survey

582 National Center

Reston, Virginia 22092

Publications Sales:

Books and Open-File Reports Section

U.S. Geological Survey

Federal Center, Box 25425

Denver, CO 80225

(303) 236-7476

Method of Payment:

Prepayment by check or money order, payable in United States funds to the Department of the Interior/USGS. 
SPOKANE OFFICE

U.S. COURTHOUSE RH. 651 WEST 920 PIVERSDE SPOKNE wa. 00201 500-353-2640 P

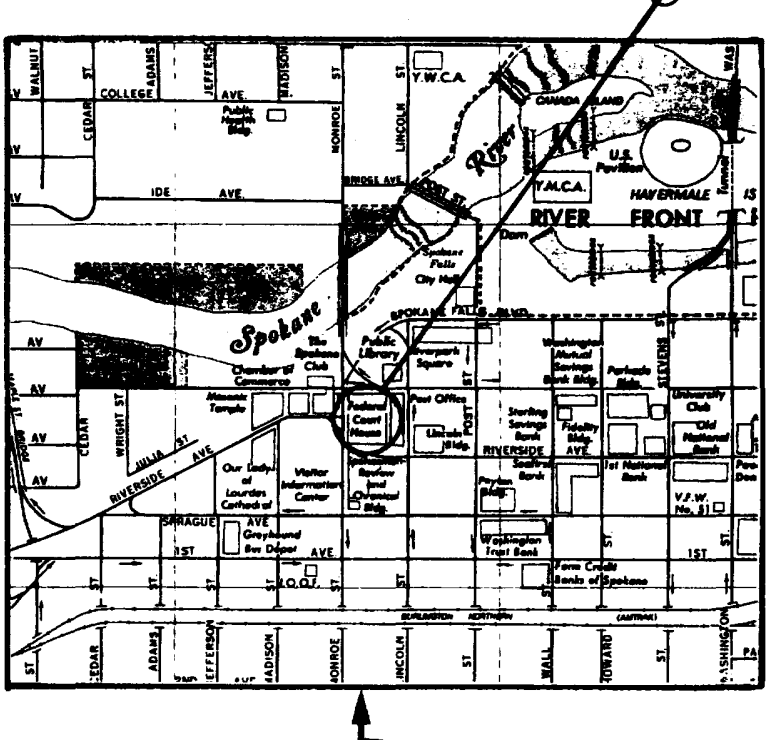

RבNO OFFCE

c/O MACKN SCHOOL OF MUES UNVERETY OF MaMDA, REAS

Q Revo,NaMDA 89557-0047 702-784-5552

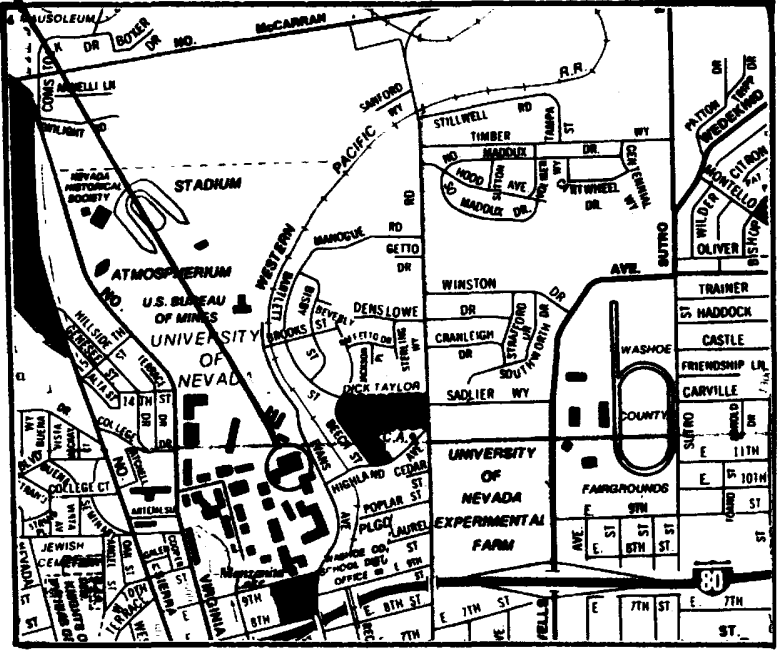

USGS

MINERALS INFORMATION

OFFICE LOCATIONS

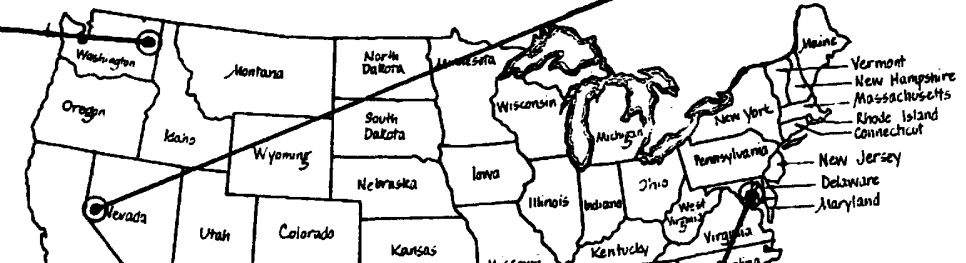

TUCSON OFFICE

WASHMETON D.C. OFFICE

CORBETT BUIDNG 210 E.7th St.

TuCSON AZ.85705 602-670-5508

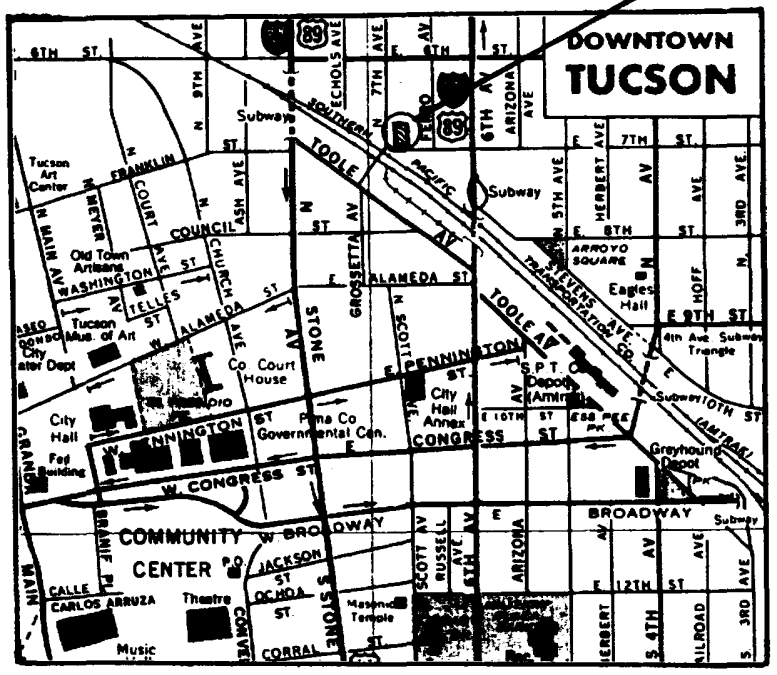

MAN ETEROOR BUWDNG,Pan.2647 18theC St MW

Q mashngton,D.C. 20240 202-343-5512

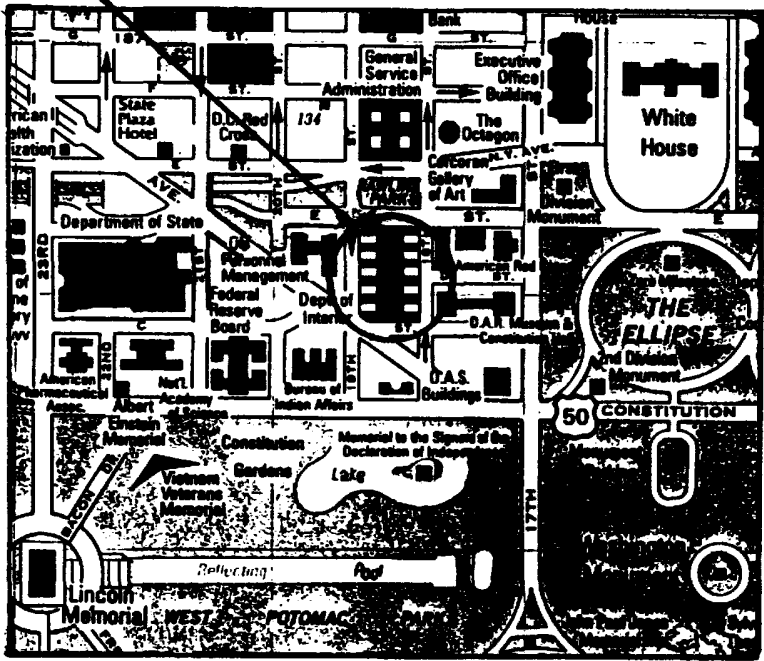

Figure 5. Locations of U.S. Geological Survey Minerals Information Offices. 


\section{MINERALS INFORMATION SOURCES IN STATE AGENCIES}

\section{Alaska}

By Milton Wiltse

Alaska's mineral resources are probably the least quantified and least developed of any of the Western States. Historically, Alaska has been a significant domestic source for copper, platinum, and gold. Alaska also has important reserves of lead, zinc, silver, molybdenum, zeolites, sand, gravel, and strategic and critical minerals, including tin, tungsten, mercury, antimony, chromium, asbestos, and rare earths. Currently, petroleum from the Prudhoe Bay field surpasses all other Alaskan resources in terms of dollar value of production. The presence of other known petroleum and natural gas reservoirs above and in the vicinity of the Prudhoe Bay reservoir, as well as offshore potential in the Bering Sea, indicates that oil and gas will continue to contribute a major share to the State's resource base even as production from Prudhoe Bay declines.

Alaska has become a major exporter of zinc, lead, and silver since the Red Dog mine in northwestern Alaska began production in 1990. The Red Dog deposit ( 85 million tons, 17.1 percent $\mathrm{Zn}, 5$ percent $\mathrm{Pb}, 2.4 \mathrm{oz} /$ ton $\mathrm{Ag}$ ) is one of several related deposits in that area. In southwestern Alaska, the Greens Creek mine on Admi- ralty Island has begun producing silver, gold, zinc, and lead from indicated reserves of 3.5 million tons of ore having a grade of $23.8 \mathrm{oz} / \mathrm{ton} \mathrm{Ag}, 0.18 \mathrm{oz} / \mathrm{ton} \mathrm{Au}$, 9.7 percent $\mathrm{Zn}$, and 3.9 percent $\mathrm{Pb}$. World-class deposits of polymetallic copper ores remain undeveloped in the Ambler region, southwestern Brooks Range. See figure 6 for locations of world-class mineral deposits in Alaska.

Alaska gold production is currently dominated by placer operations, but excellent lode-gold potential is being actively tested at several locations throughout the State. Notable areas of interest are the historic Juneau, Nome, and Fairbanks districts.

Only a small fraction of Alaska's coal resources $(170,800$ million tons indicated resources; $5,600,000$ million tons hypothetical resources) has been developed. Current annual production is about 1.5 million tons. These coals are shipped about equally to in-state and foreign markets.

The Alaska Department of Natural Resources' Division of Geological and Geophysical Surveys and Division of Mines are the primary State sources of information pertinent to the mineral resources of Alaska. The Division of Geological and Geophysical Surveys' activities are focused on scientific and technical aspects of mineral occurrences and their geologic framework. The Division of Mines concentrates on regulatory issues associated with mining in the State. The U.S. Geological Survey, the U.S. Bureau of Mines, and the U.S. Bureau

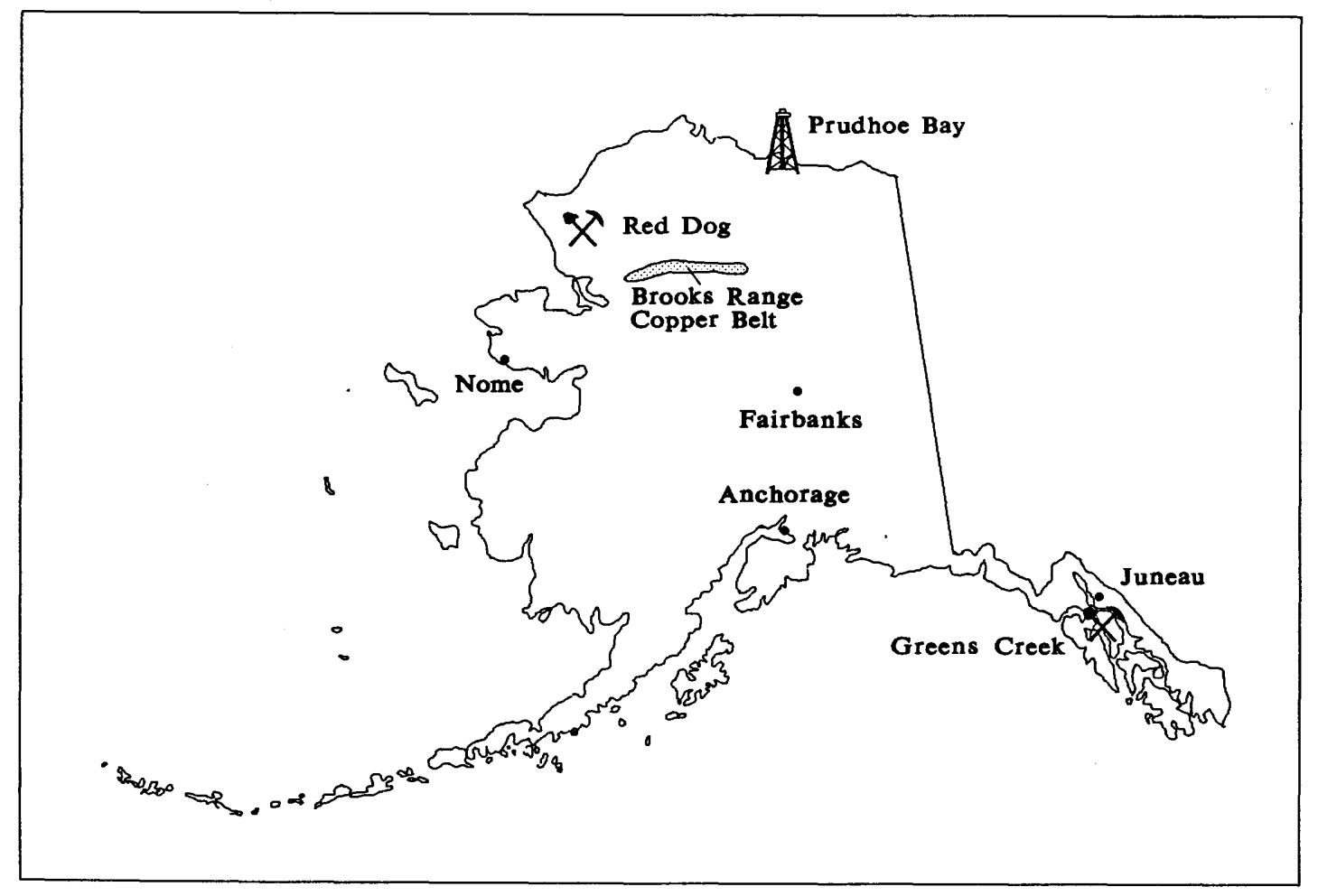

Figure 6. Index map of Alaska, with sites referred to in text. 
of Land Management are Federal sources of Alaska minerals-related information.

The Division of Geological and Geophysical Surveys has primary responsibility for generating geologic information concerning Alaska's mineral resources. Data are acquired through field studies, cooperative programs with other State and Federal agencies, and contracts. The results of agency studies are made available to the public through the following series of publications for sale at the Fairbanks Office of the Geological and Geophysical Surveys: Public Data Files, Reports of Investigation, Special Reports, Geologic Reports, Information Circulars, Outside Publications, and Contract Reports.

Interested persons would find Information Circular 11 ("Reports and Maps Issued by the Alaska Division of Geological and Geophysical Surveys, revised June 1985") and Information Circular 23 ("Map of Division of Geological and Geophysical Surveys' Publications with Author and Quadrangle Indexes, revised July 1985") of particular help in ordering pertinent Surveys' publications. These and other Information Circulars are available free of charge from the Division's Fairbanks Office.

In cooperation with the Alaska Division of Business Development and the Alaska Division of Mines, the Division of Geological and Geophysical Surveys publishes an annual summary of Alaska's mineral industry as part of its Special Report series. This document provides a comprehensive overview of yearly mining activities and bears the title "Alaska's Mineral Industryyear."

The Division of Geological and Geophysical Surveys' archives include unpublished Prospect Examination Reports that date from Alaska Territorial days and the complete data set from the federally sponsored, statewide National Uranium Resource Evaluation (NURE) program. The NURE data base includes stream- and lake-sediment geochemical analyses of over 60,000 data points distributed across 100 of Alaska's 153 quadrangles. These data are available in hard copy format for use on-site at the Division's Fairbanks Office. Air-radiometric profiles compiled for quadrangles evaluated during the NURE program also are available for on-site use.

The Division of Geological and Geophysical Surveys maintains a core storage facility at Eagle River, Alaska, about 20 miles north of Anchorage. The facility is open to the public and contains drill cuttings from oil wells and complete or skeletonized core donated by various mining companies.

The agency is a repository for U.S. Geological Survey and U.S. Bureau of Mines publications. The public can use these documents on-site at the Fairbanks Office.
The Alaska Department of Natural Resources' Division of Mines maintains records of State and Federal mining claims, and State mining permits and leases in Alaska. The Division of Mines records are available for public use at the Mining Information Office in Fairbanks. The Mining Information Office has microfiche records of all Federal claims in Alaska. A microcomputer-based claims record system has been developed that includes all active State mining claims. An on-site terminal provides a data link with the State's central Land Action System (LAS) located in Juneau, Alaska. The LAS data base contains the current land status information for Alaska State lands and State mining claims. Historic State and Federal mining claim information can be accessed via the Division's Cardex file of inactive claims. Clear mylar overlay maps depicting approximate claim boundaries at a scale of 1:250,000 are available for active and inactive State and Federal claims. No distinction of claim status is made on these maps. Mining information staff will provide out-of-town customers with claims status information for specific areas on a time-available basis. Arrangements can be made to copy pertinent documents and land status maps. Charges depend on costs of reproduction.

The University of Alaska, Fairbanks, has several departments that provide information pertinent to mineral resources. The Department of Geology and Geophysics offers B.S., M.S., and Ph.D. programs that result in the publication of dissertations pertinent to the mineral resources of Alaska. These publications are available through the campus library. The School of Mineral Engineering also offers advanced degrees in mineral-related subjects. The Mineral Industry Research Laboratory conducts field and laboratory studies focused on the mineral resources of the State. The results of their research are published in reports available through the Mineral Industry Research Laboratory office on the university campus. The University of Alaska Geophysical Institute, Fairbanks, maintains a library of aerial photography and satellite imagery at their Geo-data Center. Imagery can be viewed and copies ordered at their facility.

\section{Mineral Information Facts at a Glance-Alaska}

General mineral resource inquiries and publication sales:

Division of Geological and Geophysical SurveysInformation available on (in Fairbanks, unless otherwise noted) annual summary on the mineral industry in Alaska; indexes of Alaska Geological and Geophysical Surveys reports and maps; unpublished prospect evaluations; drill core/cuttings in Eagle River; National Uranium Resource Evaluation data for Alaska; repository of U.S. Geological 
Survey and U.S. Bureau of Mines publications in Fairbanks:

3700 Airport Way

Fairbanks, AK 99510

(907) 451-2760

State Geologist, Robert Forbes

Deputy State Geologist, Tom Smith

Publication Sales, Joyce Outten

Anchorage Office

3601 C Street, Suite 1236

P.O. Box 107005

Anchorage, AK 99510

(907) $762-2356$

Regional Geologist, Wyatt Gilbert

Eagle River Office

18225 Fish Hatchery Road

P.O. Box 772116

Eagle River, AK 99577

(907) 696-0070

Storage Facility, John Reeder

Juneau Office

400 Willoughby Ave., 3rd Floor

Juneau, AK 99801

(907) 465-2533

Division of Mines-Information available on (costs are based on copying charges) State and Federal mining claims and leases; historic and current data; microfiche and hard copy; digital data base; 1:250,000 maps showing claim boundaries:

3601 C Street

P.O. Box 107016

Anchorage, AK 99510

(907) $762-2163$

Director, Gerald L. Gallagher

(907) 762-2518

Mining Information Office, Robert Stuvek

Fairbanks Office

3700 Airport Way

Fairbanks, AK 99709

(907) 451-2709

Regional Manager, Judd Peterson

Mining Information Office, Eric Hanson

Information available on degree programs, theses, dissertations:

University of Alaska

Department of Geology and Geophysics

Brooks Bldg., Room 408

Fairbanks, AK 99775

(907) 474-7565

Department Head, Samuel Swanson
Information available on degree programs, theses, dissertations:

\author{
University of Alaska \\ School of Mineral Engineering \\ Brooks Bldg., Room 209 \\ Fairbanks, AK 99775 \\ (907) 474-7366 \\ Dean, Russell D. Ostermann
}

Information available on reports of field and laboratory studies in Alaska:

University of Alaska

Mineral Industry Research Laboratory

210 O'Neill Resources Bldg.

Fairbanks, AK 99775

(907) 474-7135

Associate Director, P.D. Rao

Information available on remotely sensed images (aerial photography, satellite imagery):

\author{
University of Alaska \\ Geophysical Institute Geo-Data Center \\ Elvy Bldg., Rm. 501 \\ Fairbanks, AK 99775 \\ (907) 474-7487 \\ Supervisor, Katherine K. Martz
}

For information about U.S. Geological Survey research programs in Alaska, contact:

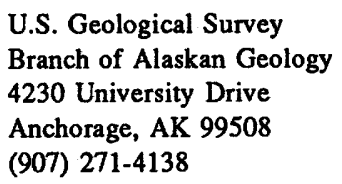

U.S. Geological Survey

Branch of Alaskan Geology

4230 University Drive

Anchorage, AK 99508

(907) 271-4138

For information about U.S. Bureau of Mines research programs in Alaska, contact:

U.S. Bureau of Mines

Alaska Field Operations Center

201 East 9th Avenue, Suite 101

Anchorage, AK 99501

(907) 271-2455

For information about Federal land status in Alaska, contact:

U.S. Bureau of Land Management

Alaska State Office

701 C. Street

P.O. Box 13

Anchorage, AK 99513

(907) 278-3343 


\section{Arizona}

By John W. Welty

The State of Arizona historically has been one of this country's leading nonfuel mineral producers. The rich diversity of geologic settings present in Arizona has allowed the economic exploitation of a wide variety of metallic and nonmetallic commodities. Over the last 30 years, Arizona has been among the Nation's top five nonfuel mineral producers. Arizona's copper production and reserves are internationally known; less well known is Arizona's importance to the Nation with regard to production of molybdenum, zinc, silver, and gold, which are all derived largely as by-products of copper mining. $\mathrm{Nu}$ merous other strategic and critical mineral commodities including lead, manganese, mercury, tungsten, uranium, and vanadium are currently or have been previously mined in Arizona. Arizona has been and continues to be an important regional and national source of industrial minerals and rock products including bentonite, cement, chrysotile (asbestos), gypsum, halite, lime, perlite, pumice, sand and gravel, and zeolites.

The geologic history of Arizona is complex, resulting in a diversity of rock types and earth materials, including those of commercial interest. Regional variations in geologic history gave rise to three geologic provinces-the Colorado Plateau, Transition zone, and Basin and Range province-and an inequitable distribution of both metallic and nonmetallic mineral wealth.

The Colorado Plateau is largely composed of flatlying Paleozoic and Mesozoic sedimentary rocks and late Cenozoic volcanic fields and sedimentary deposits (see "Geologic Time Chart" at end of report). Metallic mineral resources are primarily (1) uranium-vanadium deposits and occurrences in the Mesozoic Chinle and Morrison Formations; (2) solution-collapse breccia-pipe uranium deposits with significant concentrations of base and precious metals and rare-earth elements; (3) stratabound manganese replacement deposits in Paleozoic rocks; and (4) minor stratabound copper deposits in Paleozoic and Mesozoic rocks. Nonmetallic occurrences include bentonite, gypsum, halite, sylvite, clay minerals, specialty sands, flagstone, volcanic rock products, and aggregate.

The adjacent Transition zone features areally extensive exposures of Proterozoic rocks, economically important Devonian and Mississippian carbonate rocks, and Tertiary volcanic and sedimentary materials. Metallic mineral resources are predominantly base and precious metals. This geologic province contains Proterozoic massive sulfide deposits, Proterozoic through Tertiary baseand precious-metal vein deposits, uranium deposits in Proterozoic and Pennsylvanian to Permian rocks, and less important tungsten and manganese resources. Non- metallic resources in this province include facing and dimension stone, aggregate, decomposed granite, chrysotile (asbestos), gypsum, clay minerals, barite, fluorspar, zeolites, and several grades of limestone.

The Basin and Range province has the most complex geologic history which resulted in the most diverse mineral resources. The geologic evolution of the Basin and Range province was comparable to that of the other two provinces during Proterozoic and Paleozoic time, but diverged by early Mesozoic time when the region underwent multiple episodes of Mesozoic to early Cenozoic plutonism, metamorphism, and regional deformation. A middle Tertiary episode of crustal extension, accommodated by regional detachment faulting and commonly younger high-angle normal faulting, is primarily responsible for the present physiography of the province. The majority of Arizona's nonfuel mineral production has come from this province. The metallogeny of the Basin and Range province is dominated by the presence of large tonnage, low-grade porphyry copper deposits of both Jurassic and late Cretaceous to early Tertiary age. Subordinate to the porphyry copper deposits, but still important to mineral resource development in Arizona, are the Tertiary volcanic-rock-related, precious-metaldominant vein deposits. Base- and precious-metal, and locally significant tungsten, vein deposits of Proterozoic to Tertiary age have also been historically meaningful metal producers. The recent recognition of the significance of middle Tertiary detachment faults and associated structures in western Arizona has led to the most recent major gold discovery in Arizona, the Copperstone mine. Miocene strata in the Artillery Mountains area of the Basin and Range province host North America's largest manganese resource. Minor uranium resources also exist in middle and late Tertiary lake-bed sequences. Industrial mineral occurrences are likewise diverse, including halite, gypsum, clay minerals, aggregate, decomposed granite, diatomite, zeolites, perlite, pumice, kyanite, limestone, marble, dimension stone, and semi-precious stones. In addition, young stream deposits yield vast quantities of sand and gravel, Arizona's economically most important nonmetallic mineral commodity.

The Arizona Geological Survey is the primary State agency responsible for mineral resource studies and geologic mapping within the State. The Arizona Geological Survey has been mandated by the State legislature to (1) inform the public in matters concerning the geological environment and the development of mineral resources in Arizona; (2) encourage the wise use of the lands and mineral resources of Arizona; (3) provide technical advice and assistance concerning geology to other State and local governmental agencies engaged in projects in which the geologic setting or the mineral resources of Arizona are involved; and (4) provide techni- 
cal advice and assistance concerning geology to the mineral industry and other members of the public to encourage the wise development and use of the mineral and land resources of Arizona. The Arizona Geological Survey investigates, describes, and interprets the geologic setting of Arizona, including its natural hazards and limitations, its natural attributes, and its mineral resources.

The results of the agency's research are reported annually in the "Arizona Geological Survey Annual Report, [year]." As part of a continuing program to better understand the mineral endowment of Arizona, the Arizona Geological Survey staff pursues a vigorous program of geologic mapping within and around areas of known mineralization. Where appropriate, the field studies are supplemented by geochemical, geochronological, and laboratory studies to provide a greater understanding of the genesis of Arizona mineral deposits. The Arizona Geological Survey also maintains data bases and data collections as a resource for the mineral explorationist. These collections include: (1) a compilation of mineral production data, bibliographic citations, ore deposit model classifications, and assorted file data for all 456 metallic mineral deposits in Arizona (a similar compilation is being prepared for the known industrial mineral and rock product localities in Arizona); (2) a compilation of radiometric age determinations in Arizona $(1,699 \mathrm{~K}$ $\mathrm{Ar}, \mathrm{Ar}-\mathrm{Ar}, \mathrm{Rb}-\mathrm{Sr}$, fission-track, isotopic lead, and leadalpha age determinations that have been indexed by ascending age order, geographic area, formation or rock unit name, and original sample number); (3) a collection of drill core, largely donated by the mineral exploration industry, and well cuttings from oil and gas borings with drill logs and some geophysical logs; and (4) a collection of unpublished reports and maps, theses, dissertations, geologists field notes, and obscure U.S. Atomic Energy Commission reports pertinent to the geologic setting of Arizona (maintained by the Arizona Geological Survey library).

Two other State agencies, the Arizona Department of Mines and Mineral Resources and the Arizona State Land Department, also provide information relevant to mineral resources in Arizona. The primary objective of the Department of Mines and Mineral Resources is to promote the development of Arizona's mineral resources by sponsoring technical and educational activities and by providing mining, metallurgical, and other technical information and assistance to prospectors, small-mine operators, the mineral industry, and others interested in Arizona's mineral resources. The Arizona Department of Mines and Mineral Resources maintains the following collections: (1) an information bank and library of mineral and mining information, including books, periodicals, films, videotapes, and individual mine files; (2) a repository of underground mine maps and mine data; (3) a mineral museum, as the State depository of ores, gemstones, lapidary material, and other valuable mineral specimens. The Arizona State Land Department administers some 9.5 million acres of land held in trust for the State's public schools and 13 other beneficiaries. The Nonrenewable Resources and Minerals Section of the State Land Department manages subsurface leasing activities and nonrenewable resources to generate revenue for the 14 State Trust beneficiaries. In addition to overseeing mineral-material sales, the Nonrenewable Resources and Minerals Section issues: prospecting permits; mineral, oil and gas, and geothermal leases; and permits for geophysical prospecting. Ancillary programs include research on proposed land sales and exchanges, environmental impact studies, reviews of mining and reclamation plans, and contracting of archeological surveys and excavations.

In April of 1988, the U.S. Department of the Interior announced the establishment of an office in Tucson, Ariz., to facilitate coordination of U.S. Geological Survey and U.S. Bureau of Mines mineral resource research, assessment, and informational activities with other Federal, State, and local agencies in the southwestern United States. The purpose of the U.S. Geological Survey's Tucson Field Office is to (1) establish closer communication with State and local governments, industry, and other Federal agencies with interests in the resources of the southwestern United States and Latin America; (2) develop and maintain a digital mineral resource information base for this region; and (3) improve the areal expertise of the U.S. Geological Survey in mineral resources through detailed studies of the region's mineral deposits and mining districts. Also, the U.S. Geological Survey has opened a Minerals Information Office in cooperation with the Arizona Geological Survey at the State Survey Office. The Minerals Information Office, a new endeavor of the U.S. Geological Survey, complements the services available from the Arizona Geological Survey and makes the location a "one-stop shopping place" for mineral resource information. The Minerals Information Office staff provides information about and access to U.S. Geological Survey minerals data bases, commodity specialists, and publications for the benefit of the public, industry, and State and Federal officials. The office also seeks to improve the exchange of information among Federal agencies and other mineral information users. The Tucson office of the U.S. Bureau of Mines provides regional and local representation and contact with the mineral-producing industries, government agencies, and mineral-consuming public in Arizona, New Mexico, and Utah. Specific duties of U.S. Bureau of Mines staff, in Tucson, include the following: (1) providing a liaison between the U.S. Bureau of Mines and top industry and State officials; (2) interfacing with State and local mineral-related agencies, private 
companies, educational and research institutions, the media, and the public; (3) authoring analytical assessments of various aspects of the mineral industry; (4) monitoring mineral-related activities of interest to the U.S. Bureau of Mines and U.S. Department of the Interior; (5) determining issues or concerns that impact the mineral industry and suggest means for their resolution; (6) analyzing and interpreting data on mineral deposits and assessing identified mineral resources; (7) describing and delimiting mineralized zones and developing probabilistic reserve and resource evaluations; and (8) estimating capital and operating costs for mining and metallurgical systems.

\section{Mineral Information Facts at a Glance-Arizona}

General mineral resource inquiries and publications sales:

Arizona Geological Survey

845 North Park Avenue, \#100

Tucson, AZ 85719

(602) $882-4795$

Office hours: 8:00 a.m. to 5:00 p.m.-Monday through Friday

(see fig. 7 for location)

This office offers the following services, at no charge unless otherwise noted:

-Specimen/sample identification

- Core library (available by appointment)

-Well cuttings repository

-Newsletter; "Arizona Geology," published quarterly, free to U.S. residents

-List of publications, over 300 publications pertaining to the geology of Arizona updated annually

- Most popular publications (contact the above address for postage and handling charges):

Geologic Map of Arizona, Map 26, $\$ 5.00$

Arizona Lode Gold Mines and Gold Mining, Bulletin 137, $\$ 7.50$

Metallic Mineral Districts and Production in Arizona, Bulletin 194, $\$ 7.00$

-Data bases:

Digital

Metallic mineral districts

Bibliography for metallic mineral districts

Radiometric age composition

Oil and gas well locations, logs, and cuttings library

Thesis/dissertation index on Arizona geology

Conodont color alteration index

Geologic mapping in Arizona

\section{Nondigital}

Industrial mineral and rock occurrences

Metallic mine site files

For information on mine development in Arizona, contact:

Arizona Department of Mines and Mineral Resources

Mineral Bldg., State Fairgrounds

Phoenix, AZ 85007

(602) $255-3791$

Office hours: 8:00 a.m. to 5:00 p.m.-Monday through Friday

Directories of Earth Science Clubs, Exploration Offices, Active Mines, Arizona Mining Consultants, and "The Primary Copper Industry of Arizona in [year]" are published annually, and copies of the laws and regulations governing mineral rights in Arizona are available from this agency.

For information on mineral exploration on State Trust lands, contact:

\author{
Arizona State Land Department \\ Nonrenewable Resources and Minerals Section \\ 1616 West Adams Street \\ Phoenix, AZ 85007 \\ (602) 255-4628 \\ Office hours: 8:00 a.m. to 5:00 p.m.-Monday through Friday
}

For information about U.S. Geological Survey research programs in Arizona and other southwestern region states, contact:
U.S. Geological Survey
Tucson Field Office
University of Arizona
Gould-Simpson Bldg., \#77
Tucson, AZ 85721
(602) $670-5500$

Office hours: 8:00 a.m. to 5:00 p.m.-Monday through Friday

For information about U.S. Bureau of Mines research programs in Arizona and other southwestern region states, contact:

U.S. Bureau of Mines

Corbett Building

210 East 7th Street

Tucson, AZ 85705

(602) $670-5110$

Office hours: 8:00 a.m. to 5:00 p.m.-Monday through Friday 


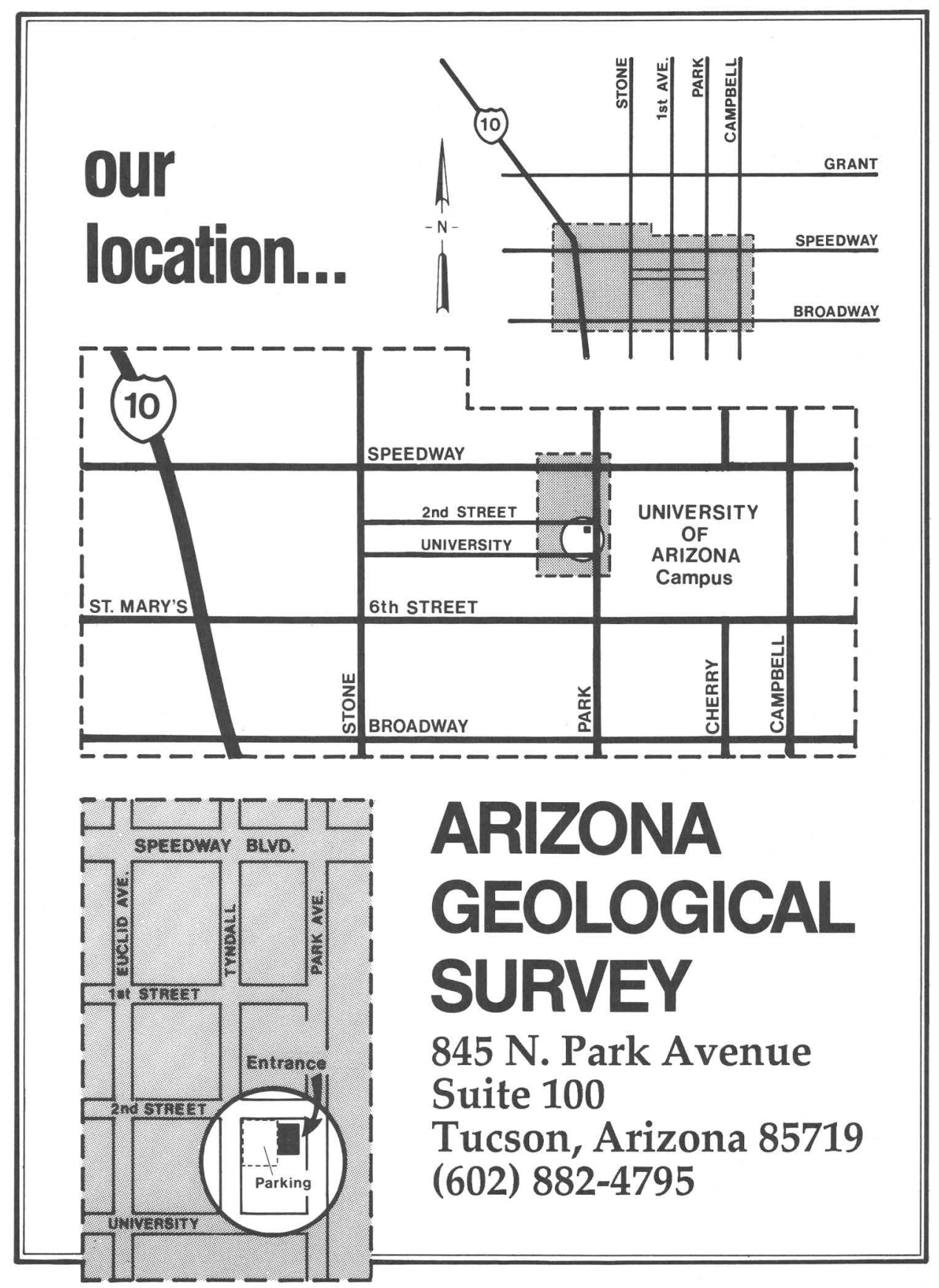

Figure 7. Location of Arizona Geological Survey, Tucson, Arizona. 


\section{California}

By Ralph Loyd and John Rapp

The State of California is well known for its great wealth and diversity of mineral resources. There are 78 nonfuel minerals known to be mined within the State, about half of which are being mined at the present time. California is the sole producer of borate minerals in the Nation, is the source of over half the total world rareearth minerals production, and leads the Nation in the production of portland cement, diatomite, calcined gypsum, asbestos, construction sand and gravel, and tungsten. California also ranks high among the States in the production of gold, natural calcium chloride, magnesium compounds, and sodium compounds. There are about 1,000 producing mines in California, the largest group being construction aggregate, with other industrial minerals and metal mines ranking second and third respectively. The State's mineral production for 1988 is estimated to be valued at over $\$ 2.7$ billion.

Producing mines are located in 57 of the 58 counties and in all of the 11 geomorphic provinces of the State. A five-county area in the desert region of southeastern California is considered to be one of the most important mineral repositories in the world. Over 25 different types of minerals valued at $\$ 1.3$ billion were mined in the desert region during 1987.

The California Department of Conservation, Division of Mines and Geology is the State agency responsible for mineral resource studies and geologic mapping within the State. Mineral resource studies are carried out by personnel in the Division's Mineral Resources Development Program. This program provides government decision makers, industry, and the public with current information regarding mineral potential and mining activity in California. Emphasis is placed on providing information which can be used to make prudent decisions in areas of the State where development of mineral resources is threatened by proposed land uses that are incompatible with mining. The Division also provides technical assistance to local government agencies concerning reclamation of mined lands.

Products generated by the Mineral Resource Development Program include (1) maps and reports classifying land according to the presence, absence, or likely occurrence of economically significant mineral deposits; (2) computerized data bases related to mining activities, mineral resources, and specific mineral commodities; and (3) topical economic geology studies. This information is available through the Division's Public Information and Sales Office. Program accomplishments are summarized and published annually in the "Report of the State Geologist" and in the "Annual Report of the State Mining and Geology Board."
Mineral resource related publications of the Division are:

-Geologic Data Maps-Small-scale $(1: 750,000)$ statewide maps showing geology, gravity data, active faults, earthquake epicenters, geothermal sites, and other geologic features.

-Regional Geological and Geophysical Maps.-A map series published at $1: 250,000$ and $1: 100,000$ scale which shows regional geology, active faults, magnetic data, gravity data, and other geologic features. This series includes maps of offshore areas.

- Map Sheets.-Large-scale $(1: 62,500$ and $1: 24,000)$ geologic maps related to mineral resource or geologic-hazards studies. These maps are commonly released with explanatory Special Reports or Special Publications.

- Mineral Land Classification Reports.-A series of reports which includes large-scale maps $(1: 48,000$ and $1: 62,500)$ showing mineral resource potential and local geology in certain areas of the State.

-Special Reports and Special Publications.-Publications used to disseminate the results of many of the Division's project studies, selected topical geologic studies, and newly generated data such as the "List of Mineral Producers Active in California."

"California Geology."-A monthly magazine published by the Division of Mines and Geology which includes articles that have broad appeal to readers who have interest in the geology, mineral resources, and geologic hazards of California.

- Open-File Reports.-Open-file reports generally include preliminary reports and large-scale maps showing geologic, geophysical, mineral resource, or geologic hazard data.

"DMG Notes."-The Division of Mines and Geology distributes a series of informational notes and pamphlets covering various geologic topics.

Mineral resource related services of the Division are:

- Computerized Mineral Property Data Base.-The Division of Mines and Geology is currently developing a computerized index system and files on mineral properties located in California. Named MINEFILE.DBF, this system will provide rapid access to existing mineral property reports and information related to active and idle mines and mineral properties throughout the State.

-Public Information Service.-Public information staff are located at each of the Division's regional offices listed below to assist in finding pertinent publications and answering general questions. The staff commonly arranges direct public contact with the Division geologist who has expertise in the areas of the inquirer's interest. 
- Research Library Service.-The Division of Mines and Geology maintains a central and branch library system which is accessible to the public for research purposes. Book lending is possible through interlibrary loan service.

\section{Mineral Information Facts at a Glance-California}

General mineral resource publications sales and inquiries:

Division of Mines and Geology publications are distributed through the regional offices located in Los Angeles, Pleasant Hill, and Sacramento, or they can be ordered through the mail. For list of the available publications and ordering information write:

Department of Conservation Division of Mines and Geology P.O. Box 2980

Sacramento, Califomia 95812

(916) 445-5716
Division of Mines and Geology Office locations (see fig. 8):

Office of the State Geologist

1416 9th Street, Room 1341

Sacramento, CA 95814

(916) $445-1923$

Public Information, Sales, and Library Services 660 Bercut Drive

Sacramento, CA 95814

(916) 445-5716

Bay Area Regional Office, and Branch Library 380 Civic Drive

Pleasant Hill, CA 94523-1997

(415) $671-4920$

Southern California Regional Office

107 South Broadway, Room 1065

Los Angeles, CA 90012

(213) $620-3560$

Office hours: 8:00 a.m. to 5:00 p.m.-Monday through Friday 
BAY AREA REGIONAL OFFICE

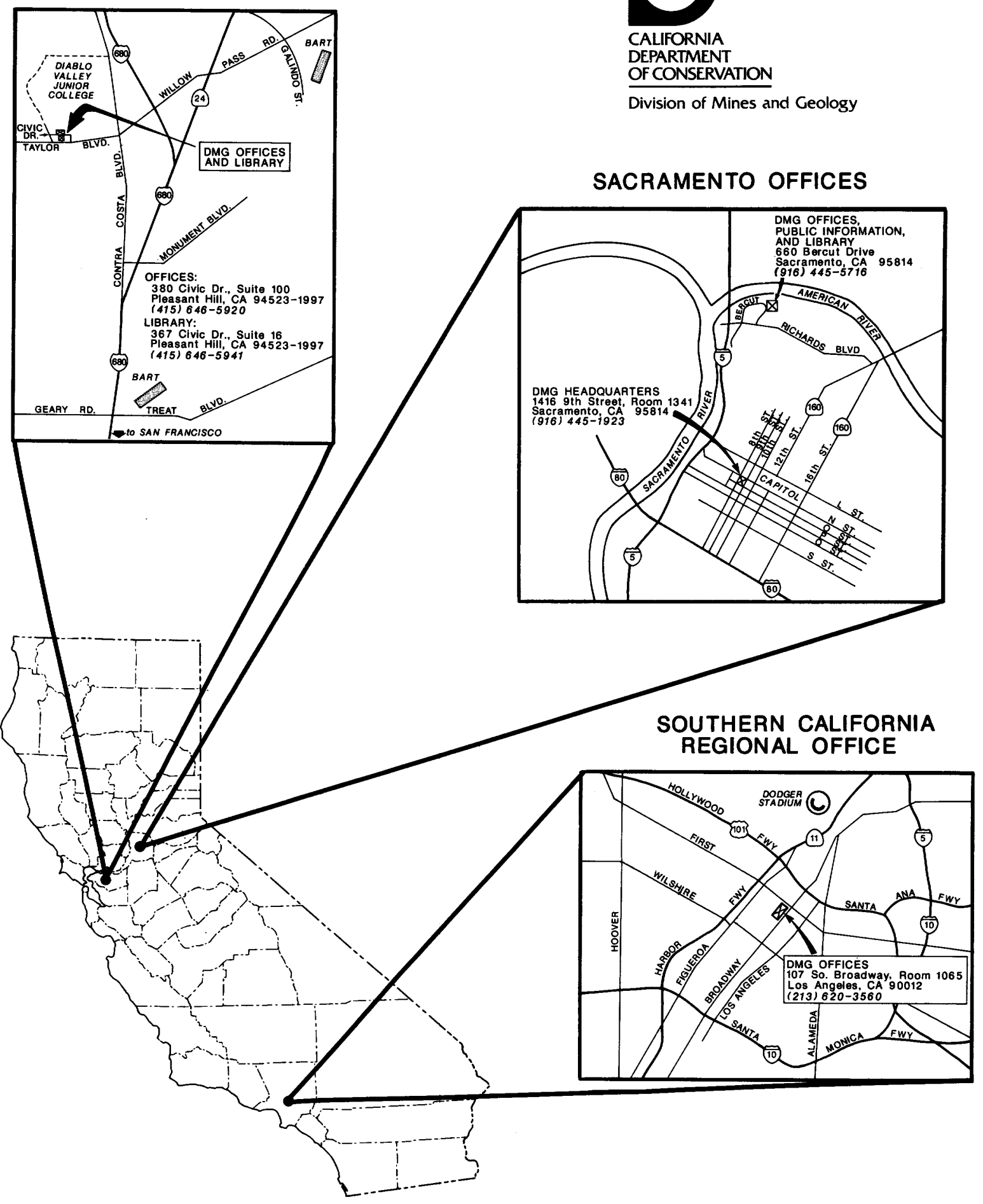

Figure 8. Locations of Division of Mines and Geology offices in California. 


\section{Colorado}

\section{By Mark Davis}

The State of Colorado contains diverse mineral resources. Colorado is a leading producer of molybdenum and an important producer of gold, silver, lead, and zinc. During the early 1980's the price of gold increased to over $\$ 800 / \mathrm{oz}$, a level which encouraged many companies to explore the gold-producing states. Old mines were reopened and their waste rock was analyzed and in many cases reprocessed. Cripple Creek, Colorado, was of great interest because it is a historic gold-producing area. Cripple Creek had produced over 20 million ounces of gold. Much gold remained in the mine dumps and was amenable to modern extraction methods, such as heap leaching. This historic mining district is once again producing gold.

Uranium and vanadium have been produced from the Colorado Plateau in southwestern Colorado and from the vanadium deposits at Rifle and Placerville. At one time, radium and thorium were also produced; radium from plateau sediments and thorium from veins in the metamorphic rocks of the Wet Mountains. Thorium demand is relatively low now, but greater reliance on nuclear power generation and conversion to high-temperature gas reactors could greatly increase demand.

Industrial minerals form a major part of Colorado's mineral resources. Alluvial sand and gravel and quarried aggregate have been very important to the growth of Colorado. There is constant demand for these materials. Colorado has excellent deposits of both chemical- and cement-grade limestone that are currently under production. The State contains many deposits of both brick quality and refractory clays. The wall board industry is currently expanding in Colorado as excellent deposits of gypsum are developed on the western slope. Also on the western slope are large resources of oil shale that may become economic if refining technology improves and oil prices increase. Occurring with the oil shale, and also separately, are substantial reserves of nahcolite which have sparked recent industry interest.

Colorado has huge undeveloped resources of certain strategic minerals that could supply significant percentages, if not all, of the national requirements for those commodities. Columbium, titanium, and aluminum mineral resources fall into this category. Their development, however, is dependent on one or more of several economic factors including a decrease in the availability of relatively cheap imports, technological breakthroughs in improved beneficiation and recovery, government subsidies, availability of large amounts of venture capital, and, in the case of aluminum from dawsonite, on largescale development of oil shale in areas containing saline minerals.
Other strategic mineral commodities have been produced in Colorado in the past. Deposits of these minerals have the potential to supply lower but still significant percentages of the Nation's strategic mineral requirements. These deposits include tungsten, titanium, tin, and, fluorspar. Future production of tungsten and fluorspar is more dependent on favorable price structure than on any other factor. Tin, produced as a by-product of molybdenum, is dependent on production at Climax, Colo. Current research conducted by the U.S. Department of the Interior's Bureau of Mines Salt Lake City Research Center points to a technologic breakthrough in recovery of titanium from perovskite. Preliminary results of research indicate an almost twofold increase in the extraction of titanium from perovskite concentrate. Previous methods recovered only about 50 percent of the titanium; however, the new process recovers more than 95 percent. This new improved process of recovering titanium from concentrate is an example of technologic breakthroughs needed to allow economic recovery and production of domestic strategic minerals.

Colorado has an extremely varied dimension stone industry. Many years of production of sandstone have provided sidewalks and facing stone on many buildings, including most buildings on the campus of the University of Colorado.

White marble has been produced from the famous Yule Marble Quarry in western Colorado. The mine is currently being evaluated for resumption of production. The Yule marble has been used at the Lincoln Memorial and the Tomb of the Unknown Soldier in Washington, D.C., as well as many buildings in Denver and other major cities. Alabaster has also been mined in Colorado from quarries near Livermore and at Owl Canyon northwest of Fort Collins.

Rock hounds and collectors are always interested in minerals and gems. Colorado offers some excellent opportunities for prospecting for these materials. Popular sites include amethyst near La Garita, topaz near Taryall, Apache tears at Los Pinos, smoky quartz near Devil's Head Mountain, and many others. Diamonds associated with kimberlite pipes near the Wyoming border form the most noteworthy gem occurrence in Colorado.

\section{Mineral Information Facts at a Glance-Colorado}

General mineral resource inquiries and publication sales:

Colorado Geological Survey

1313 Sherman Street, Suite 715

Denver, Colorado 80203

(303) 866-2611

Office hours: 8:00 a.m. to 5:00 p.m.-Monday through Friday

This office offers the following services at no cost, unless otherwise noted: 
-Specimen/sample identification

-Building stone and quarry identification

-Newsletter published annually

-Selected U.S. Geological Survey maps available for sale

-Free brochures on a variety of topics of general interest including mineral collecting, fossil collecting, and gold panning

This office maintains a geologic library, geologic hazards library, microfiche and reader, printouts from Federal mineral resource data bases, and many U.S. Geological Survey publications.
The following State resource agencies are located at the same address as the Colorado Geological Survey:

Colorado Mined Land Reclamation Division (303-866-3567), which oversees mine permitting and includes the Colorado Division of Mines

Colorado Land Board (303-866-3454), which is responsible for leasing State land

Colorado Water Resources Division (303-866-3581) 


\section{Hawaii}

The geology of Hawaii is one of the State's most interesting features. Information and referrals concerning the geology, and volcanoes, as well as limited minerals data, can be obtained from:

\section{Chairperson}

State of Hawaii

Department of Land and Natural Resources

P.O. Box 621

Honolulu, HI 96809

(808) 548-6550 
By Earl Bennett

Idaho leads the nation in the production of silver, garnet, and vanadium. In addition, Idaho claims about 10 percent of the Nation's phosphate production. The State's mines also produce considerable gold and nonmetallic materials including pumice, zeolites, perlite, limestone, building stone, silica, and sand and gravel. The mining industry has the highest-paid industrial work force in the State and is the fourth major contributor to the State's economy, following agriculture, timber, and electronics.

Idaho's mineral wealth is a direct result of its geology. The largest silver-producing district in the world is located in Precambrian rocks of the Belt Supergroup in Shoshone County in the northern panhandle of the State, while large resources of phosphate are mined from the Phosphoria Formation of Permian age in the southeastern corner of Idaho (see "Geologic Time Chart" at end of report). A gold rush of historical proportion is underway throughout the old gold mining districts of central and southern Idaho. Many of these deposits are hosted by plutonic and volcanic rocks ranging from Cretaceous to Tertiary in age. Other deposits include a major molybdenum mine in Custer County and massive sulfides in the accreted terrane of Permian to Triassic age in western Idaho. Industrial minerals are actively mined throughout the State and exist as large undeveloped resources. These resources include perlite, pumice, diatomite, silica, limestone, zeolite, and garnet.

The Idaho Geological Survey is the lead State agency for the collection, interpretation, and dissemination of all geologic and minerals data for the State. The results of the agency's research are released through several series of publications, including bulletins, information circulars, pamphlets, county reports, various kinds of maps, and technical reports. There are over 435 of these publications listed in the annually updated "List of Publications," available at no cost. Especially useful for minerals information is the Mines and Prospects map series (scale 1:250,000) that lists information for about 8,000 mines and prospects in the State, and the companion Geologic Map Series, that shows the State's geology. The Idaho Geological Survey also publishes an annual report of its activities and research efforts and a report of all mining activity and development in the State.

The Survey maintains an electron microprobe laboratory and has access to other laboratory equipment shared with the College of Mines and Earth Resources at the University of Idaho. A limited number of free semiquantitative analyses are available to the State's citizens and the lab does most routine rock and mineral identifications at no cost.
General mineral resource inquiries and publication sales:

Main Office

Idaho Geological Survey

332 Morrill Hall

University of Idaho

Moscow, ID 83843

(208) 885-7991

\section{Branches}

Boise Branch Office Idaho Geological Survey 1910 University Drive

Math-Geology, Room 104

Boise State University

Boise, ID 83705

(208) 385-4002

Pocatello Branch Office Idaho Geological Survey P.O. Box 8071

Idaho State University

Pocatello, ID 83205

(208) $236-3235$

Office hours: Winter-8:00 a.m. to 5:00 p.m.-Monday through Friday. Summer-7:30 a.m. to 4:30 p.m.-Monday through Friday

These offices offer the following services at no cost, unless otherwise noted:

-Free literature conceming the mineral industry and other aspects of the State's geology and mineral resources are available in the Survey's offices. Most important is the annually updated "List of Publications," listing all Survey publications and containing forms and information for mail orders.

-Copies of all Idaho Geological Survey publications may be purchased at the main office or ordered by mail from the branch offices. Customers can mail orders to the main office using forms provided in the free "List of Publications."

-The Idaho Geological Survey is an authorized sales outlet for all U.S. Geological Survey topographic maps for Idaho. These include 1:24,000-, 1:62,500-, 1:100,000-, 1:250,000-, and $1: 500,000$-scale maps.

- The Idaho Geological Survey library contains information about the geology and ore deposits of Idaho and is available to the public during normal working hours. Microfiche and copying equipment is available in the library area.

-The Survey will provide a limited number of free semiquantitative analyses of minerals and rocks to Idaho citizens. The Survey will also identify a limited number of rocks and minerals at no cost. Contact: Charles R. Knowles, Idaho Geological Survey, 332 Morrill Hall, University of Idaho, Moscow, ID 83843. (208) 885-6785.

-For information concerning mining operations, regulations or other minerals information contact: Earl H. Bennett, State Geologist, 332 Morrill Hall, University of Idaho, Moscow, ID 83843. (208) 885-6860. 
Data bases available to library users (Note: Currently none of the following data bases are in a digital format. However, the Idaho Geological Survey is presently building digital data bases for the Geologic Map Series, Mines and Prospects Series, and a new State bibliography based on the 1:250,000-scale format):

- Copies of all Idaho Geological Survey publications

-Mines and Prospects Map Series-Information on 8,000 mines and prospects in the State. Most references are available in the library

-Individual files on most industrial mineral and rock commodities for the State

-The U.S. Geological Survey Mineral Resource Data System (MRDS) for Idaho

-The U.S. Bureau of Mines Mineral Industry Location System (MILS) for Idaho

-All National Uranium Resource Evaluation reports and data for Idaho

-A listing of all of the Federal Defense Minerals Exploration Administration and Office of Minerals Exploration studies done in Idaho. Very few of the reports are available in the library. The U.S. Geological Survey in Spokane, Washington, does have many of the Defense Minerals Exploration Administration and Office of Minerals Exploration study reports on file

-Annual reports for about 500 of the leading mining companies in the world
-Annual reports on all Idaho mining companies

-An extensive newspaper clippings file covering about 10 years of mining and related activity in Idaho

-Geologic Map Series-Compilations of State geology at a scale of 1:250,000. An ongoing index keeps track of new additions. Most references are available in the library

-All U.S. Geological Survey open-file reports for Idaho

-All U.S. Bureau of Mines open-file reports for Idaho

-Indexes to all U.S. Geological Survey and U.S. Bureau of Mines publications

-Files on all industrial mineral and rock localities and operations in Idaho

- Copies of most U.S. Bureau of Mines and U.S. Geological Survey publications that deal with the geology and mineral resources of Idaho

-State Mine Inspector's Reports (1899-1979) and indexes. Many of the original reports filed with the State Mine Inspector are available in the IGS library

-U.S. Bureau of Mines Yearbook chapters for Idaho (1893present)

-U.S. Bureau of Land Management mining claim location microfiche. Updated every three months

-Copies of many M.S. and Ph.D. theses on the geology and ore deposits of Idaho

- Oil and gas logs for all holes drilled to date

-Earthquake and seismic records for the State

-Selected aerial photography (various formats and scales) and Landsat imagery covering Idaho 


\section{Montana}

By Richard Berg

Montana produces a variety of mineral commodities, both metallic and nonmetallic, as well as coal, petroleum, and natural gas. Major metals produced in the State are copper and silver from metasedimentary rocks of the Proterozoic Belt Supergroup, palladium and platinum from the Archean Stillwater Complex, copper and molybdenum from the Cretaceous Boulder batholith, and gold, silver, lead and zinc from vein deposits related to Tertiary igneous rocks, both intrusive and extrusive (see "Geologic Time Chart" at end of report). Twelve industrial mineral commodities as diverse as vermiculite and sapphire are also mined. In recent years, Montana has been the leading State in value of talc produced. Eight additional industrial mineral commodities have been mined in the past. Montana is a substantial producer of subbituminous and lignite coal with estimated strippable reserves of 50 billion tons. The diverse geologic environments, particularly in the western part of the State, provide opportunities for the discovery of additional mineral resources.

The Montana Bureau of Mines and Geology, a department of the Montana College of Mineral Science and Technology, is the primary source of information on the State's mineral resources. The active geologic mapping program includes areas with significant mineral potential. Publications specifically dealing with mineral resources include the results of investigations of individual mining districts and reports on industrial mineral commodities. Information on mineral deposits gleaned both from published and unpublished sources is entered into the Montana Mine and Mineral Data System. Information entered into this system has been released in hard copy format for two counties with plans to release more as it becomes available. A similar program for the State's coal resources is the National Coal Resource Data System (NCRDS), a cooperative program between the Montana Bureau of Mines and Geology and the U.S. Geological Survey. Information entered into this system is used in publishing reports on the coal resources of specific areas.

An annual directory of mining enterprises lists active mines and many mines in the development stage. Another annual report concentrates on new developments in the mining industry and includes information on exploration activities. An annual list of geologic research activities includes studies on mineral resources by faculty, students, and State and Federal agencies.

Files of unpublished information on mines, including some mine maps, are available for inspection and photocopying. The Anaconda Research Collection, con- taining over 12,000 vein and wall rock specimens from the Butte ore body, many with accompanying thin sections and mineralogical information, is available for detailed study. The Mineral Museum situated on the Montana Tech campus has over 1,200 specimens on display, many from famous mining districts. Three short courses offered annually by the Montana Bureau of Mines and Geology cover placer mining, prospecting, and important aspects of development, mining and milling. The Montana Tech Library has substantial holdings dealing with mineral resources and more than 700 theses dealing with Montana geology.

Although all staff members are available to provide assistance in their areas of expertise, Robin McCulloch, the Staff Field Agent, is the main source of information on mineral deposits and the mineral industry in general. His phone number is (406) 496-4171. The Staff Field Agent visits mining properties, offering helpful advice to the operators of small mines at their request. In those instances where more extensive assistance is required, the individual is encouraged to employ qualified consultants. Rock and mineral specimens are identified on a routine basis and the individual submitting the material is advised about further testing if the samples are indicative of possible economic deposits.

\section{Mineral Information Facts at a Glance-Montana}

General mineral resource inquiries and publication sales:

Main Office

Montana Bureau of Mines and Geology
Montana Tech
Main Hall, Room 200
Butte, MT 59701
(406) 496-4174 or 496-4167
Office hours: 8:00 a.m. to 5:00 p.m.-Monday through Friday
(see fig. 9 for location)
Billings Office

Montana Bureau of Mines and Geology

Eastern Montana College

1500 North 30th Street

Petro Hall, Room 321

Billings, MT 59101

(406) $657-2938$

Office hours: 8:00 a.m. to noon and 1:00 p.m. to 5:00 p.m.Monday through Friday

Available in Butte office (Note: All publications orders must be paid for in advance by cash, check, or money order):

-Montana Bureau of Mines and Geology publications (out of print publications available on loan) 


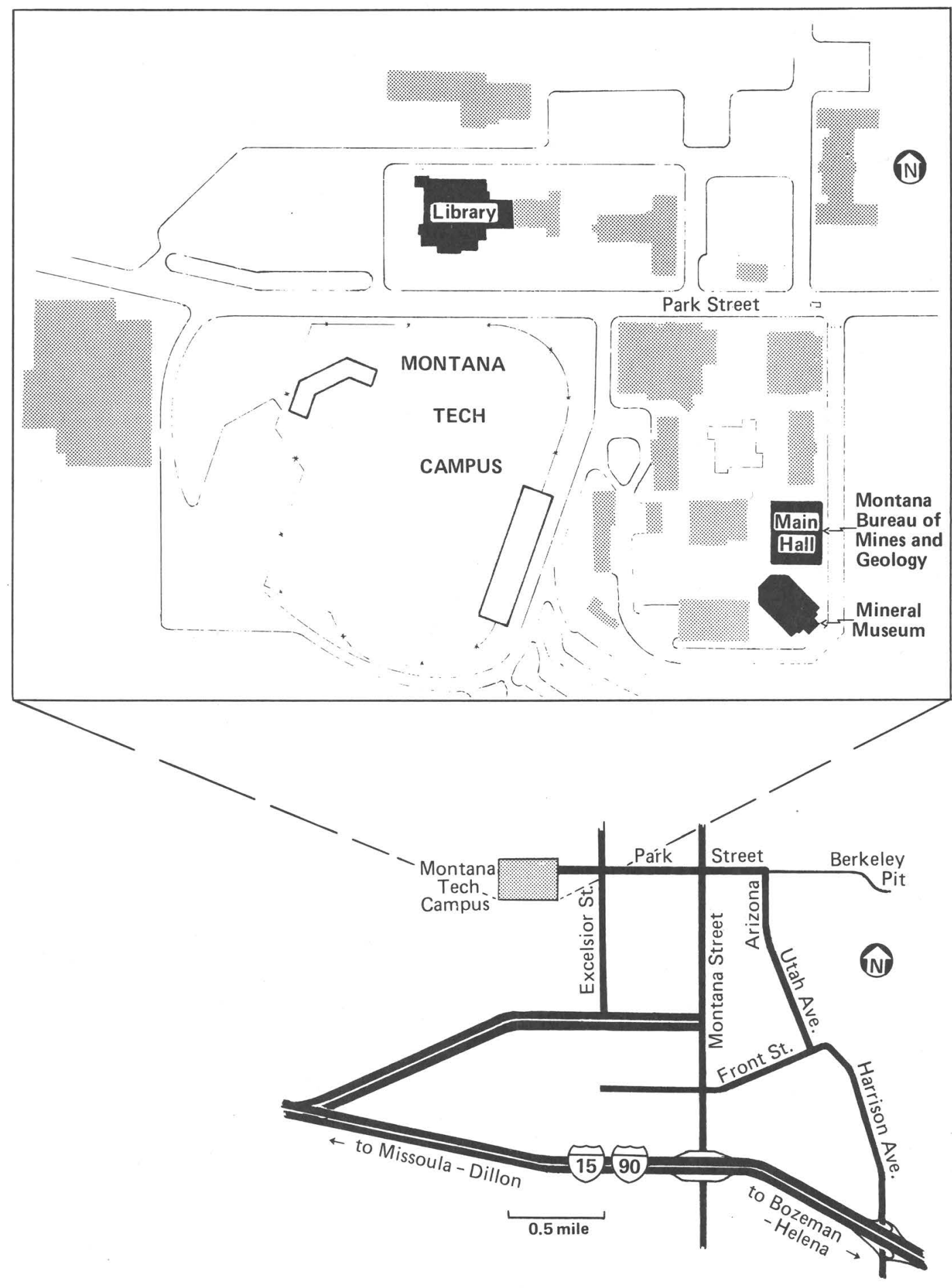

Figure 9. Location of Montana Bureau of Mines and Geology, Butte, Montana. 
-Montana Bureau of Mines and Geology Open-File Reports and Maps $^{6}$

-U.S. Geological Survey geologic maps and some bulletins and professional papers on Montana geology

-U.S. Geological Survey topographic maps for Montana

-Various publications of other organizations, including geologic guidebooks, are available for sale

-Free catalog of publications distributed by the Montana Bureau of Mines and Geology

- Bibliography on metallic mineral deposits

-Index of theses on Montana geology

-Popular publication: "Montana in the Geologic Past" by Perry

-Pamphlet Series (new series, first pamphlet on Butte)

-This office is an Earth Science Information Center and as such provides ordering information for aerial photos and maps from a variety of sources

Montana Bureau of Mines and Geology is not engaged in any regulatory activities. For information on regulations governing exploration and mining activities any- where in Montana and leasing minerals on State lands contact:

\author{
Department of State Lands \\ 1625 Eleventh Avenue \\ Helena, MT 59601 \\ (406) 444-2074
}

Office hours: 8:00 a.m. to 5:00 p.m.-Monday through Friday

The Department of State Lands is the lead agency in obtaining permits for mining. The State Historic Preservation Office, the Air Quality Bureau and Water Quality Bureau of the Department of Health and Environmental Sciences, and the Department of Natural Resources are also frequently involved in the permitting process. The Hard Rock Mining Impact Board is responsible for negotiations between local government units and large-scale mineral developers.

'U.S. Geological Survey Open-File Reports and Maps are available in the Montana Tech Library as are more than 700 theses dealing with Montana geology. 


\section{Nevada}

\section{By Becky Weimer Purkey}

Nevada is well endowed with mineral wealth and ranked third in the U.S. in total nonfuel mineral production in 1989 (U.S. Bureau of Mines data). Nevada is the leading domestic producer of gold, silver, and barite and is the sole U.S. producer of mined magnesite and mercury. Other mineral commodities mined in Nevada are sand and gravel, crushed stone, petroleum, clay, gemstones, gypsum, copper, diatomite, fluorspar, iron ore, lime, lithium minerals, molybdenum, portland cement, and salt.

The Nevada Bureau of Mines and Geology is a research and public service unit of the Mackay School of Mines at the University of Nevada, Reno and is the State geological survey. Other units of the Mackay School of Mines, specifically the academic-teaching departments of chemical and metallurgical engineering, mining engineering, and geological sciences, conduct research in mining, exploration, and mineral processing technologies. The Nevada Bureau of Mines and Geology conducts research in three broad categories: mineral resources, environmental studies, and geologic mapping.

Current studies of mineral resources include mineral resource assessments of military land withdrawals, U.S. Bureau of Land Management resource areas, the Reno 30 - by 60 -minute quadrangle, Elko County, and the entire State; epithermal gold-silver deposits; metallic mineral deposits associated with porphyritic igneous rocks; bulk-mineable mineral deposits in Nevada; borates, copper, mercury, and hydrothermal platinum group metal deposits in Nevada; ultra-potassic igneous rocks; bastnaesite stability studies; solubility of platinum group metals in hydrothermal solutions; trace-element geochemical signatures in advanced argillic alteration zones of the Reno-Virginia City area; assay standards for precious metals; distribution of anions in soils around an epithermal gold deposit in eastern Nevada; economic impacts of mining in Nevada; and applications of geographic information systems (GIS) to mineral resources and other aspects of geology.

Current environmental studies include neotectonics of Nevada; Quaternary faulting and neotectonics of the Yucca Mountain area; preliminary investigation of radon hazards; Quaternary geology of southern Nevada; earthquake hazards; debris flows and landslides; and land subsidence due to ground-water withdrawal.

Geologic mapping is progressing on various quadrangles, primarily at $1: 24,000$ and $1: 100,000$ scales.

The information gained in geologic and mineral resource studies is published in scientific journals and in Nevada Bureau of Mines and Geology bulletins, reports, maps, open-file reports, special publications, data bases, and newsletters. In addition, Nevada Bureau of Mines and Geology staff members present papers at professional meetings, give lectures, lead field trips at State and National geological symposia, conduct tours of Nevada Bureau of Mines and Geology facilities, and answer questions in person and by letter and telephone.

Publications by the Nevada Bureau of Mines and Geology and other agencies and individuals are on display and available for purchase in the publications sales office. A publications list and order form will be sent free upon request. This office also carries a complete collection of U.S. Geological Survey topographic and geologic maps of Nevada.

The Nevada Bureau of Mines and Geology also maintains an open-file information office. Inquiries are handled in person or by letter or telephone. General categories of information located and maintained in this office include oil, gas, and geothermal and production statistics, engineering geology reports; mining district records and maps; mineral resources and reserves; mineral resource assessments; wilderness study areas; general geologic studies; indexes and ordering information for maps, air photos and remote sensing imagery; a core and cuttings library; mining claim data; and the Nevada Bureau of Mines and Geology, U.S. Geological Survey, U.S. Bureau of Land Management, U.S. Bureau of Mines, and U.S. Department of Energy open-file reports concerning the geology and mineral resources of $\mathrm{Ne}$ vada. The various information banks are accompanied by $1: 1,000,000$-scale index maps, and some of the information in the office is available through our computer data base search and retrieval system in computer data base listings. Selected bibliographies are maintained on some subjects, and all files are being updated on a continuous basis. Pamphlets on various geological and cartographic subjects and rock/mineral samples are provided free to the public through this office. This office is the Nevada State affiliate for the U.S. Geological Survey's Earth Science Information Center, and the U.S. Geological Survey established a regional Minerals Information Office here in 1989.

The Nevada Bureau of Mines and Geology runs a geochemical laboratory for its research projects and for serving the citizens of Nevada. Rocks are analyzed for many elements. The fee is $\$ 5$ per element per sample. Gold and silver fire assays are $\$ 10$ per sample. X-ray fluorescence and $\mathrm{x}$-ray diffraction analyses are also available.

The Nevada Bureau of Mines and Geology has no regulatory functions but cooperates fully with State and Federal agencies that regulate mining, petroleum and geothermal production, and engineering activities. Mining and oil, gas, and geothermal drilling operations are regulated on the State level by several offices including 
the State Mining Inspector, the Nevada Department of Minerals, the Department of Conservation and Natural Resources (Division of Environmental Protection), all of which are located in Carson City, and the Department of Wildlife, which is located in Reno.

Currently, approximately 86 percent of Nevada is public land. The U.S. Bureau of Land Management operates offices around the State to regulate mining and oil, gas, and geothermal drilling operations on Federal land. The Nevada State Office of the U.S. Bureau of Land Management is located in Reno and includes mining claim recordation, mineral resources, biological resources, planning and environmental coordination, engineering, cadastral survey, lands and minerals operations, mapping and photogrammetry, and public information divisions.

\section{Mineral Information Facts at a Glance-Nevada}

General mineral resource inquiries:

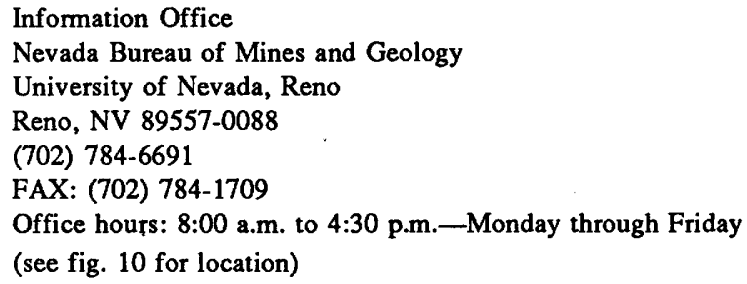

Publications and map sales office (method of payment of publications: cash, check, MasterCard, Visa, or money order; all mail orders must be prepaid):

- Nevada Bureau of Mines and Geology publications list (free)

-Annual list of active mines (published as Special Publications, or contact the Geologic Computer Specialist for an updated list)

-Nevada Bureau of Mines and Geology publications

-U.S. Geological Survey topographic and geologic maps of Nevada

-Nevada Geology" quarterly newsletter (free)

-Books, articles, and maps on Nevada geology, rock and mineral collecting, and mining history by publishers other than Nevada Bureau of Mines and Geology (not listed in the Nevada Bureau of Mines and Geology publications list)

-Assays (\$5.00 per element per sample, and $\$ 10.00$ per sample for gold and silver by fire assay). For more information, contact the Chief Chemist/Geochemist

-Data bases (see publications list). For more information contact the Geologic Computer Specialist

-Out-of-print, open-file, and unpublished reports and maps available for inspection and copying

For information on State mining and oil, gas, and geothermal drilling, leasing, and regulation, contact:

Nevada Department of Minerals

400 West King Street, Suite 106
Carson City, NV 89710

(702) 687-5050

Nevada Division of Mine Inspection

1380 South Curry Street

Carson City, NV 89710

(702) $687-5243$

Nevada Department of Conservation and Natural Resources

201 S. Fall Street

Carson City, NV 89710

(702) $687-4360$

Division of Environmental Protection

123 West Nye Lane

Carson City, NV 89710

(702) 687.4670

Nevada Department of Wildlife

1100 Valley Road

Reno, NV 89512

(702) 789-0500

Office hours for the above State agencies: 8:00 a.m. to 5:00 p.m.-Monday through Friday

For information on Federal mining and oil, gas, and geothermal drilling, leasing, and regulation, contact:

\section{U.S. Bureau of Land Management \\ 850 Harvard Way \\ P.O. Box 12000 \\ Reno, NV 89520-0006 \\ (702) 785-6500 (Public Room)}

Mineral Resources Division-(702) 785-6576

Mining Claim Recordation-(702) 785-6510

Lands and Renewable Resources Division-(702) 785-6464

Office hours: 7:30 a.m. to 4:15 p.m.-Monday through Friday

For additional information on mineral commodities and production statistics in Nevada, contact:

\author{
Fred Carrillo, State Mineral Officer \\ Reno Regional Office of State Activities \\ U.S. Bureau of Mines \\ 1605 Evans Avenue \\ Reno, NV 89512 \\ (702) 784-5215 \\ Office hours: 8:00 a.m. to 4:30 p.m.-Monday through Friday.
}

For information on mineral resources and access to U.S. Geological Survey data bases, contact:

Susan M. Marcus

U.S. Geological Survey-Minerals Information Office

c/o Mackay School of Mines

Scrugham Engineering Mines, Room 313A

University of Nevada, Reno

Reno, NV 89557-0047

(702) 784-5590 


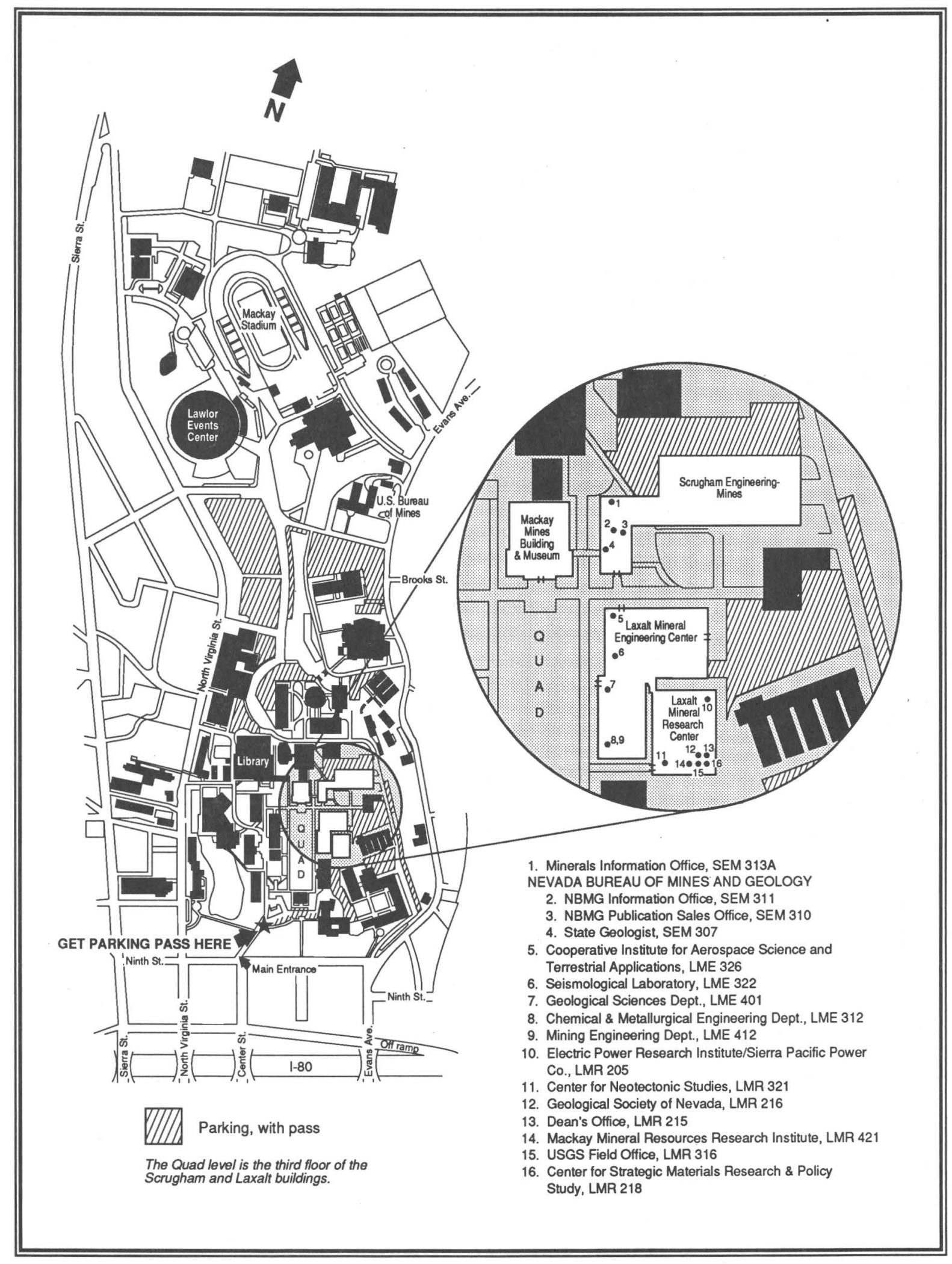

Figure 10. Location of Nevada Bureau of Mines and Geology, and related offices, Reno, Nevada. 


\section{New Mexico}

By James Barker

New Mexico is a major producer of minerals, materials, and energy. The value of nonfuel mineral production slightly exceeded $\$ 1$ billion in 1988 , with metals accounting for more than 70 percent of the total. Petroleum and natural gas accounted for $\$ 1.041$ and $\$ 1.359$ billion, respectively, in 1988. The value of natural gas liquids production was about $\$ 700$ million. The value of coal production for 1988 was $\$ 498$ million; uranium production was $\$ 50$ million. Total value of New Mexico fuel and mineral production in 1988 was approximately $\$ 4.6$ billion

The wealth and diversity of its mineral, material, and fuel resources make New Mexico a national force in mineral production. New Mexico ranks first in production of potash and perlite and second in carbon dioxide, copper, pumice, and mica. Other resources include sand and gravel, crushed stone, scoria, travertine, humate, portland cement, gypsum, and gold. New Mexico ranked seventh in the production of petroleum, fourth in the production of natural gas, third in the production of uranium, and thirteenth in the production of coal (fourth among Western States). The reserve base is equally robust. For example, New Mexico's reserves rank seventh nationally for petroleum, fifth for natural gas and coal, and first for uranium and carbon dioxide.

The potential for mineral resource occurrences is enhanced by the diverse geology of New Mexico. Rocks range from Paleozoic marine sediments to modern gypsum sand dunes and from Precambrian metamorphic rocks to extensive Tertiary volcanic fields and calderas (see "Geologic Time Chart" at end of report). Geologic provinces and features juxtaposed in New Mexico include the Southern Rocky Mountains, Colorado Plateau, Southern Basin and Range, Rio Grande rift, Delaware Basin, Datil-Mogollon volcanic field, and the Great Plains. Considerable mineral and fuel resources lie undiscovered within these terranes.

The New Mexico Bureau of Mines and Mineral Resources is a division of the New Mexico Institute of Mining and Technology and, by statute, functions as the State geological survey for New Mexico. The director of the Bureau is the State Geologist. The Bureau is the primary source of information on New Mexico's geology and most natural resources. The Bureau conducts ongoing applied and basic research in a number of areas, including environmental geology, geophysics, hydrogeology, geothermal resources, industrial minerals and coal, metallic ores, metallurgy and geochemistry, mineralogy and $\mathrm{x}$-ray analysis, oil and gas, and paleontology. The service activities of Bureau staff members are wide ranging. Many staff members teach classes in their respective areas of expertise. A primary function of the Bureau staff is to interact with the public in person, over the telephone, and by mail. Assistance provided by the Bureau includes meetings in the field, if appropriate. The Bureau also performs assays and analyses of natural resource and water samples using modern techniques and instruments. Staff members present results of their research at national and local professional meetings, give lectures, and lead field trips.

The results of the many endeavors of the Bureau are published in scientific journals, guidebooks, and in Bureau bulletins, circulars, memoirs, open-file reports, resource maps, hydrologic reports, computer data bases, "New Mexico Geology," and other formats. These publications are available for inspection and purchase through the Publication Sales Office. Also available are U.S. Geological Survey and U.S. Bureau of Land Management topographic, land status, and geologic maps of New Mexico, as well as New Mexico Geological Society publications and maps. Publications lists for the New Mexico Bureau of Mines and Mineral Resources, New Mexico Geological Society, U.S. Geological Survey, and open-file reports are available upon request.

The New Mexico Bureau of Mines and Mineral Resources maintains in its Geotechnical Information Center a repository of data relative to the mines, minerals, fossils, and geology of New Mexico. More than 4,000 maps, published and unpublished, are available at the Geotechnical Information Center including the following categories:

$\begin{array}{ll}\text { mine } & \text { geophysics } \\ \text { claim } & \text { hydrology } \\ \text { district } & \text { resource } \\ \text { assay } & \text { soils } \\ \text { geology } & \text { structure } \\ \text { geochemistry } & \text { topography }\end{array}$

More than 5,000 books, reports, and graduate theses from the U.S. Geological Survey, U.S. Bureau of Mines, New Mexico Bureau of Mines and Mineral Resources, universities, mining companies, and consultants have been collected, encompassing topics such as:

\begin{tabular}{|c|c|}
\hline $\begin{array}{l}\text { coal } \\
\text { industrial minerals } \\
\text { metals } \\
\text { stone } \\
\text { uranium } \\
\text { geology } \\
\text { geochemistry } \\
\text { ground water } \\
\text { earthquakes } \\
\text { flooding } \\
\text { hazardous waste } \\
\text { landslides }\end{array}$ & $\begin{array}{l}\text { geothermal energy } \\
\text { mineralogy } \\
\text { abandoned mines } \\
\text { mine safety } \\
\text { mine reclamation } \\
\text { mine subsidence } \\
\text { mining engineering } \\
\text { mining history } \\
\text { mining law } \\
\text { mineral processing } \\
\text { heap leaching } \\
\text { solution mining }\end{array}$ \\
\hline
\end{tabular}


A photo collection containing both historic and recent photographs, with many of the images available for use in publications, is accessible through the Geotechnical Information Center. Subjects include:

$\begin{array}{ll}\text { mine excavations } & \text { mining equipment } \\ \text { mine buildings } & \text { mining towns } \\ \text { mill buildings } & \text { mineral specimens } \\ \text { milling equipment } & \text { geologic features }\end{array}$

New Mexico geotechnical and mineral resource information is also available from a variety of computer data bases such as the U.S. Bureau of Mines' Mineral Industry Location System, U.S. Geological Survey's National Coal Resources Data System, and U.S. Geological Survey's Mineral Resources Data System. The Geotechnical Information Center is currently cataloging thousands of mining records in the collection so that rapid computerized searches may be conducted.

A major collection of minerals is housed at the New Mexico Bureau of Mines and Mineral Resources. The Mineral Museum emphasizes New Mexico minerals and fossils but also contains fine specimens from other States and Nations. The collection contains over 10,000 specimens acquired through donations, purchases, trades, and field collecting. The museum holdings are composed of the display, reserve, reference, and sale collections.

The display collection consists of all minerals and fossils currently on display in the museum. This extensive collection is subdivided into six sections. The New Mexico section contains minerals collected within the State. Other sections are devoted to minerals from other States, minerals from foreign countries, fluorescent minerals, fossils, and the Dana collection.

The reserve collection is housed in the museum storage area. Specimens that will eventually be used in the display collection or for the preparation of special displays in the museum or elsewhere are kept here. The reserve collection may be used for nondestructive studies upon request.

The reference collection consists of specimens for study including destructive procedures. These specimens exhibit the characteristics of the various mineral species and illustrate variation within mineral species. The reference collection is open to all by appointment and is used by students, prospectors, and geologists for familiarization with minerals that they may find in the field and for comparison with unidentified specimens.

Minerals offered for sale are on display in the museum. Personnel from the museum and New Mexico $\mathrm{Bu}-$ reau of Mines and Mineral Resources actively collect, buy, and trade mineral specimens to add to the collection.

The New Mexico Library of Subsurface Data is a collection of well records, geophysical logs, well samples (cuttings), fusulinid determinations, sample logs, driller's logs, oil-and-gas-pool data, pool-boundary maps, and well spot maps. These are available for inspection, free of charge, in the Petroleum Records section of the New Mexico Bureau of Mines and Mineral Resources. There is a charge for copying. Also housed here are selected production data, government publications, journals, magazines, and books pertaining to the petroleum industry. The library contains completion cards for 85,000 wells, geophysical logs for 37,000 wells, 43,500 boxes of drill cuttings from 12,900 wells, descriptions of cuttings and cores from 4,300 wells, and driller's logs from 12,100 wells. The collection continuously increases in volume.

The New Mexico Bureau of Mines and Mineral Resources Core Library contains numerous drill cores from throughout the State. Most are derived from mineral exploration ventures and some from petroleum exploration. Cores are available for inspection by appointment.

\section{Mineral Information Facts at a Glance- New Mexico}

General mineral resource inquiries and publication sales:

New Mexico Bureau of Mines and Mineral Resources

A Division of New Mexico Institute of Mining and Technology Socorro, NM 87801

(505) $835-5420$

FAX:(505)835-6333

Office hours: 8:00 a.m. to 5:00 p.m.-Monday through Friday (all services)

(see fig. 11 for location)

Services and products available at Socorro:

-New Mexico Bureau of Mines and Mineral Resources publications and maps (free catalog available)

-U.S. Geological Survey topographic and geologic maps for New Mexico

-U.S. Bureau of Land Management metric topographic and other maps

-New Mexico Geological Society guidebooks, special papers, and maps (free catalog available)

- Geotechnical Information Center (free pamphlet available)

-New Mexico Library of Subsurface Data

- Drill core library

- Mineral museum (free pamphlet available)

-Aerial photography collection

-General photo collection (historic and recent views)

- National Coal Resources Data System

- Clay mineral laboratory

-X-ray laboratory

-Perlite laboratory

-Metallurgy laboratory

-Soils laboratory

-Analytical laboratory

-Specialized data bases and files maintained by staff

Annual events hosted by the New Mexico Bureau of Mines and Mineral Resources: 


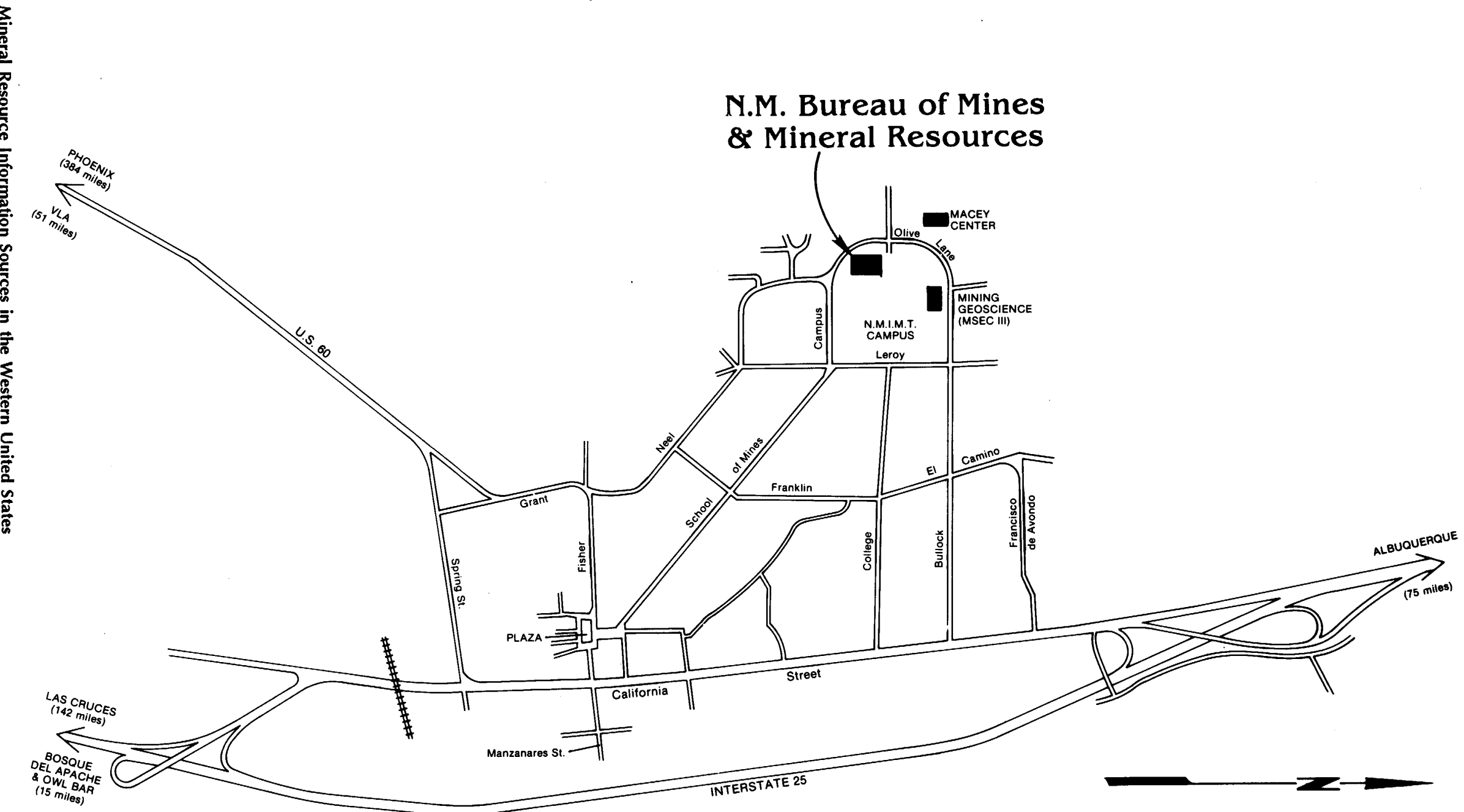

Figure 11. Location of New Mexico Bureau of Mines and Mineral Resources and selected public facilities, Socorro, New Mexico. 
- New Mexico Mineral Symposium (November)

-New Mexico Geological Society Annual Spring Meeting (April)

The New Mexico Bureau of Mines and Mineral Resources has no regulatory functions. Exploration and development activities on State lands are handled by:

New Mexico State Land Office

Box 1148

Santa Fe, NM 87501

(505) $827-5774$

All mining activities must be registered annually with:

Mining and Minerals Division

New Mexico Energy, Minerals, and Natural Resources Dept.

2040 S. Pacheco

Santa Fe, NM 87505

(505) $827-5923$
Drill holes penetrating a ground-water aquifer must be coordinated with:

State Engineer

101 Bataan Memorial Building

Santa Fe, NM 87503

(505) $827-6175$

Mining claims must be filed, within time limits, both with the county in which they are located and with:

U.S. Bureau of Land Management

Mining Claim Recordation

Box 1449

Santa Fe, NM 87504

(505) $988-6000$ 


\section{Oregon}

By Jerry Gray

\section{Mineral Resources Overview}

Minerals, which include metals, industrial minerals, and fuels, are a continuing source of new wealth and raw materials in Oregon. During 1988, the value of the output from Oregon's mines was $\$ 170$ million. Bright spots in Oregon's mineral resources are natural gas production, continuing high level of oil and gas exploration, expansion of industrial minerals production, and new precious metal discoveries. New mines and processing plants can offer year-round employment and stable tax bases in rural portions of Oregon that historically have depended on seasonal and cyclical industries such as agriculture, tourism, and forestry.

The varied geologic environments in Oregon contain many potentially valuable deposits of industrial minerals, including bentonite clay, limestone, diatomite, talc, pumice, and perlite. Changing market patterns in the Western United States and other Pacific Rim nations suggest major opportunities for Oregon's economic diversification and development.

The development of local sources of industrial minerals can assist existing businesses and give Oregon operators a competitive advantage. Some Oregon industries are dependent on industrial minerals that are currently produced in other States. As rail shipping rates rise, it will be important to locate mineral raw materials closer to plant sites. The production of industrial minerals can also stimulate port activity as Oregon products are shipped to foreign markets.

Every community in the State benefits directly from the mineral industry, which provides indispensable supplies of sand and gravel, crushed rock, and other building materials.

Continuing concerns over energy supplies have prompted efforts to identify and develop traditional resources such as natural gas. Numerous private concerns continue to lease lands and explore extensively for gas and oil. In 1988, various companies drilled 14 oil and gas wells in the State, drilling a total of 61,523 feet. Seven wells were completed in the Mist Gas Field in northwest Oregon, where 1988 production was 4 billion cubic feet of natural gas.

Oregon appears to have excellent potential for the development of geothermal energy, and thousands of acres of public domain and State land have already been leased for exploration purposes. In relatively recent geologic time, volcanoes spewed many cubic miles of lava across much of Oregon, and the earth is still very hot in many places at depth. Geothermal fluids and steam can provide energy for electrical generation and natural hot water for domestic and commercial uses; deep drilling will be required to locate such reservoirs.

The State of Oregon is home to a variety of mineral and metallurgical industries that refine exotic metals for high technology applications. Production from the State's metallurgical plants is worth approximately $\$ 1$ billion annually.

Oregon's metallic mineral resources are found both onshore, in mining districts that have been historically important to the State, and in offshore deposits. As exploration methods improve, future onshore and offshore discoveries can be expected. These resources include important amounts of strategic metals, such as chromium, cobalt, nickel, and titanium. During times of international crisis, local sources can be expected to supply important amounts of these critical commodities. Recently, the search for gold deposits has become more active, with emphasis on the southeastern quadrant of the State, where recently discovered deposits are being tested by drilling and sampling. Cominco Resources International, Ltd. of Vancouver, British Columbia, through a subsidiary (Cominco American Resources, Inc.) restarted the former M.A. Hanna Company ferro-nickel plant at Riddle. The smelter is being operated under the name Glenbrook Nickel.

\section{Role of the Oregon Department of Geology and Mineral Industries}

The Department of Geology and Mineral Industries was formed July 1, 1937. It is the only agency of State government that is responsible solely for subsurface resources. Department staff is also responsible for chairing the interagency State Map Advisory Committee, which coordinates preparation of various types of onshore and offshore digital and topographic maps. They participate in the State-Federal Technical Task Force, which evaluates the economic and environmental impacts of offshore mineral development.

The Department's responsibility is to develop, store, and disseminate geologic information about the State to serve as a basis for prudent decisionmaking in resource development and land management. The Department generates geologic maps that are invaluable tools in planning for the wise use of land and water, in the search for mineral and energy mineral resources, in the evaluation of geologic hazards, and in the assessment of environmental impacts. The Department is recognized as the State's major source of geologic, mining, oil, gas, geothermal, and geological hazard data. This information is made available to the public through the Department's publications and technical library.

The Department administers the Mined Land Reclamation Act that went into effect on July 1, 1972. The 
Act requires that any excavation from which more than 5,000 cubic yards of material is removed annually must be reclaimed for subsequent beneficial use. Thus, mineral production becomes an interim use of lands that later are returned to prior or higher use following careful reclamation. Although the Department is charged with enforcing the Act, many other State agencies and local governments cooperate through the Department's onestop permit system. The Department also regulates drilling for oil, gas, and geothermal energy under State law.

Exploration and production of these resources must be properly regulated from a geologic standpoint. Geology is a significant factor in the formation of the resource and it must be considered in the design and operation of wells for efficient recovery. Therefore, geologic expertise should be an integral part of the regulatory procedure.

Records and samples from deep wells are stored and reanalyzed by the Department to facilitate future exploration and enhance our understanding of the geologic framework of the State.

The responsible development of Oregon's mineral fuels can add stability to the State's economy by creating new capital investment and by helping the State attain the goal of energy self-sufficiency while protecting the environment, conserving resources, and recognizing the correlative rights of mineral owners.

\section{Mineral Information Facts at a Glance-Oregon}

\section{Department of Geology and Mineral Industries}

\author{
Main Office \\ 910 State Office Building \\ 1400 S.W. 5th Avenue \\ Portland, OR 97201 \\ Phone (503) 229-5580 \\ Office hours: 8:00 a.m. to 5:00 p.m.-Monday through Friday \\ (other times by appointment) \\ Function and Services Provided: \\ -Department headquarters (general geology and mineral inquir- \\ ies) State Geologist, Donald A. Hull \\ -Northwest Oregon Geology \\ Regional Geologist, George R. Priest \\ -Department Library \\ Librarian, Klaus K. Neuendorf \\ -Economic mineral inquiries \\ Northwest Oregon mine map depository \\ Economic Geologist, Jerry J. Gray \\ -Industrial mineral inquiries \\ Industrial minerals geologist, Ronald P. Geitgey \\ -Publications and map sales (minimum mail order $\$ 1.00$. All \\ sales final. Publications are sent post paid. Payment must \\ accompany orders of less than $\$ 50.00$ ).
}

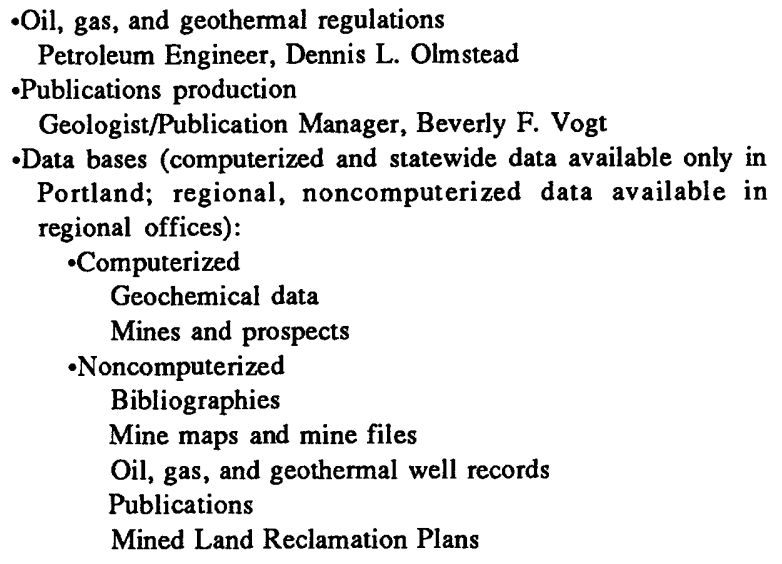

\section{Baker Field Office}

1831 First Street

Baker, OR 97814

Phone (503) 523-3133

Hours: 8:00 a.m. to 12:00 noon-Monday through Friday (other times by appointment)

Function and Services Provided:

-Eastem Oregon Geology

Regional Geologist, Howard C. Brooks

-Eastem Oregon mine map depository

-Minor publication sales

\section{Grants Pass Field Office}

\section{S.E. "H"}

Grants Pass, OR 97526

Phone (503) 476-2496

Hours: 8:00 a.m. to 12:00 noon-Monday through Friday (other times by appointment)

Function and Services Provided:

-Southwestern Oregon geology

Regional Geologist, Thomas J. Wiley

-Southwestern Oregon mine map depository

-Some publication sales

\section{Albany Field Office}

1534 S.E. Queen Street

Albany, OR 97321

Phone (503) 967-2039

Hours: 8:00 a.m. to 5:00 p.m.-Monday through Friday

Function and Services Provided:

-Regulation of the reclamation of Surface Mined Land Supervisor, Gary W. Lynch 
Utah

By Robert Gloyn and Bryce Tripp

Utah contains a wealth of mineral resources. It contains the largest beryllium mine in the world at Topaz Mountain, the deepest open-pit copper mine in the world at Bingham Canyon, and the only primary gallium/germanium mine in the United States at the Tutsagubet mining district of southwest Utah. In addition, Utah has several operating disseminated gold mines; several world-class carbonate-hosted replacement deposits; seven operating brine plants producing sodium, potassium, and magnesium salts; three cement plants; two producers of heavy clay products; and producers of phosphate, gypsum, lime, fuller's earth, crushed stone, dimension stone, rock salt, perlite, industrial sand, and uranium. In 1989, Utah ranked ninth in the value of total nonfuel mineral production in the United States. It ranked first nationally in production of beryllium, third nationally in production of copper and gold, and fourth in production of silver. In addition to known resources, Utah has good potential for undiscovered deposits of base and precious metals, particularly along defined mineral trends in the western part of the State. These areas are currently being explored and drilled by a number of mining companies.

The Utah Geologic and Mineral Survey is the primary source and repository for geologic information in the State. It is a nonregulatory agency responsible for gathering, interpreting, and disseminating information regarding Utah's geology, geologic hazards, and geologic resources. It is divided into four sections: Mapping, Applied (Hazards), Economic, and Information.

The Economic, Mapping, and Information sections of the Utah Geologic and Mineral Survey maintain hardcopy and digital data files, as well as produce numerous publications, maps, and brochures relating to mineral resources in Utah. Specific information on nonfuel resources obtainable at the Survey includes:

-A 7.5-minute geologic map series authored by the Utah Geologic and Mineral Survey, U.S. Geological Survey, and independent geologists.

-A 1- $\times$ 2-degree quadrangle-based mineral occurrence publication series, which includes sitespecific data on metallic and nonmetallic mines, prospects, and properties.

-A series of public education brochures, some of which discuss the mineral resources of Utah and the history of mining in Utah.

-Bulletins, special studies, circulars, reports of investigation, and open-file reports on mining districts, mineral commodities, areal geology, and so forth.

-A computerized data base containing detailed in- formation on the economic geology of all the known mines, prospects, quarries, pits, and so forth, in Utah.

-Knowledgeable technical personnel with expertise in metallic minerals, industrial minerals, saline minerals, geothermal resources, uranium, coal, oil/gas, and tar sands/oil shale.

In addition, the Utah Geologic and Mineral Survey publishes a free quarterly newsletter "Survey Notes," which contains information on the State's mineral resources.

Current mineral investigations at the Utah Geologic and Mineral Survey include a series of $1-\times 2$-degree quadrangle mineral occurrence maps (Tooele sheet completed; Delta sheet in progress); an industrial mineral series ("Zeolites in Utah," completed; "High Calcium Limestone in Utah," in progress); a series of reports of mining district studies ("Antelope District," completed; "Keg Mountain District," in progress); and a saline resources study ("Great Salt Lake Brines," completed; "Oil Well Brines, Sevier Lake Brines," in progress). For information on these, or other studies, contact the Utah Geological and Mineral Survey and request a free listing of available publications.

The Utah Division of Oil, Gas and Mining regulates exploration, development, and reclamation related to metallic, industrial rock and mineral, and fuel resources of Utah. For nonfuel resources, the Division of Oil, Gas and Mining maintains technical information on mineral operations from the exploration phase to the reclamation phase. The Division has data pertaining to the safe, environmentally sound extraction of mineral resources, and subsequent site reclamation. The Division produces few formal publications concerning the mineral industry, but much of the company-submitted data is available to the public. Specific examples include:

-A current list of producing companies, intermittent producers, and companies planning property developments.

-A list of exploration permits granted-includes companies planning exploration drilling and seismic surveys. Specific details regarding company name, location of exploration, and nature of deposit are kept confidential, but general information on the status of exploration in Utah is available to the public.

-An agency annual report. This report includes a brief summary of seismic surveys and drilling permitted.

-Public information brochures. Information is available describing mining in Utah, its history, and the dangers of abandoned mines.

The Utah Division of State Lands and Forestry (801-538-5508) administers the leasing of State lands for mineral development. It maintains a listing of past and 
present holders of State leases and a record of royalties paid. It also has on file some geologic information on selected mineral deposits.

In addition to the above agencies, a number of other State agencies and private organizations collect specific information on the mineral resources of Utah. These organizations and the types of information they collect are listed below.

The Utah Energy Office (801-538-5428) compiles information on production, prices, and consumption of various energy resources (oil/gas, coal, uranium, and so forth). This information is in a computerized Energy Data Information System and is also published biannually as an Energy Data Source publication. Both are available to the public.

The Utah Historical Society (801-833-5808) collects historical information on mining in Utah. They maintain a library of Utah history, which includes some mine and mining district maps, photos of historic mining operations, and old mining newspapers and reviews.

The Utah Mining Association (801-364-1874) is a trade association which represents the interests of the mining industry in Utah. It is a good source of information concerning the current activities of Utah mining companies. The association publishes a monthly newsletter, "Management Digest," which reports current mining activity.

Utah's universities and colleges conduct geologic investigations and possess a diverse body of data pertaining to mineral resources of Utah. The geology departments and the libraries at these institutions are listed below.

\author{
University of Utah \\ Dept. of Geology \& Geophysics \\ $719 \mathrm{Wm}$. Browning Building \\ Salt Lake City, UT 84112 \\ (801)581-6553 \\ University of Utah \\ Marriott Library \\ Science and Engineering, Room 158 \\ Salt Lake City, UT 84112 \\ (801)581-7533 \\ Brigham Young University \\ Department of Geology \\ Eyring Science Center, Room 258 \\ Provo, UT 84604 \\ (801)378-3918 \\ Brigham Young University \\ Harold B. Lee Library \\ Provo, UT 84604 \\ (801)378-6179 \\ Utah State University \\ Department of Geology
}

\author{
UMC 0705 \\ Logan, UT 84322 \\ (801)750-1273 \\ Utah State University \\ Merrill Library \\ UMC 3000 \\ Logan, UT 84322 \\ (801)750-2633 \\ Weber State College \\ Geology Department \\ Ogden, UT 84408-2507 \\ (801)626-7139 \\ Weber State College \\ Stewart Library \\ Ogden, UT 84408-2901 \\ (801)626-6415 \\ Southern Utah State College \\ Department of Geology \\ Cedar City, UT 84720 \\ (801)586-7911 \\ Southern State College \\ Library \\ Cedar City, UT 84720 \\ (801)586-7933
}

\section{Mineral Information Facts at a Glance-Utah}

General mineral resource inquiries and publications:

Before June 1, 1991

Utah Geological and Mineral Survey

606 Black Hawk Way

Salt Lake City, UT 84108

(801)581-6831

After June 1, 1991

Utah Geological and Mineral Survey

2363 South Foothill Boulevard

Salt Lake City, UT 84109

Office hours: 8:00 a.m. to 5:00 p.m.-Monday through Friday

(see fig. 12 for location)

This office provides the following services and information:

-All Utah Geologic and Mineral Survey maps and publications and Utah Geological Association Guidebooks are available for purchase or copying, if out of print.

-The Utah Geologic and Mineral Survey Library contains numerous publications on the geology of Utah, including published and open-file reports of the U.S. Geological Survey, university theses, U.S. Bureau of Mines, and U.S. Department of Energy publications, various technical journals, and general reference geology books.

-Map library contains geologic, geochemical, and geophysical maps (including many unpublished thesis maps), and all topographic quadrangle maps for Utah. 


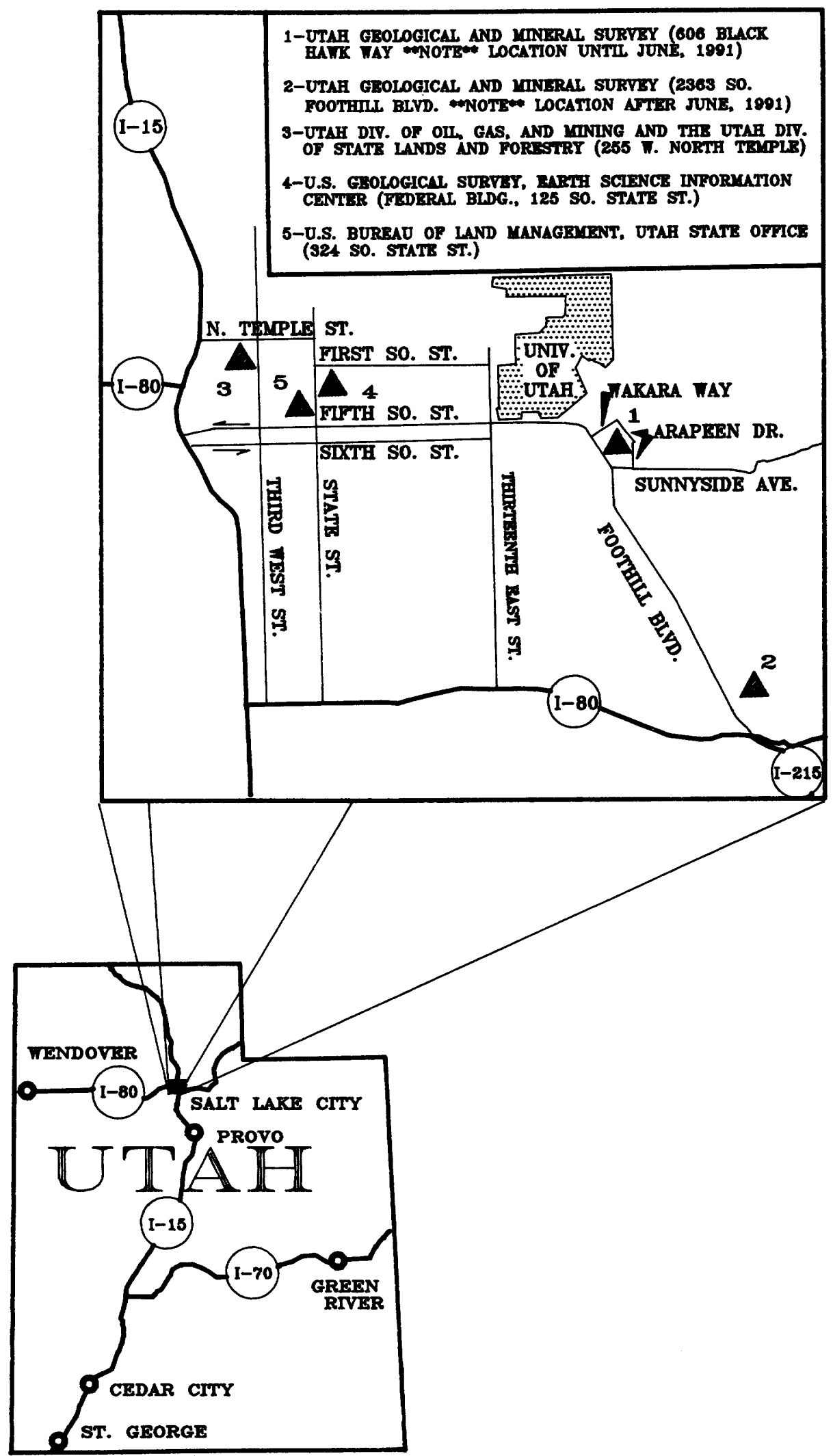

Figure 12. State and Federal minerals agencies in Salt Lake City, Utah. 
-Sample library contains core or cuttings from oil, gas, and mineral exploration drill holes, and some surface samples. Located at: 4060 South 500 West, \#4, Salt Lake City, Utah 84123, (801)266-3512

- Computerized and (or) hard copy data bases covering: Mineral occurrences-all known mines and prospects Surface/underground mine maps-microfiche Coal quality-over 1,000 analyzed samples Coal resources-over 12,000 logs and measured sections Geologic maps-over 1,700 maps

Stratigraphic sections-over 1,800 measured sections Radiometric ages-over 700 dates

Tar sands/oil shale

-Information service-geologist and technical staff available to answer questions on all aspects of Utah geology for industry and the public.

Regulations, permits, mine development, oil/gas development:

Utah Division of Oil, Gas and Mining

3 Triad Center, Suite 350

355 West North Temple

Salt Lake City, UT 84108

(801) $538-5340$

Office hours: 8:00 a.m. to 5:00 p.m.-Monday through Friday (see fig. 12 for location)

This office maintains the following information, most of which is available for public inspection:
-Well information and geophysical logs for all oil/gas wells drilled (may be confidential for up to 15 months after completion)

-Listing of oil/gas drilling permits and completed wells (monthly)

-Individual well production and disposition for all active wells

-Monthly and summary oil/gas production report

-Seismic Exploration Applications/Seismic Exploration Completion Reports

-Listing of mining operations in State (updated twice a year)

-Mine permits-Environmental Impact Statement Reports

-Exploration (reclamation) Permits (confidential)

State leases and exploration:

Utah Division of State Lands and Forestry, Jerry Mansfield

3 Triad Center, Suite 400

355 West North Temple

Salt Lake City, UT 84108

(801)-538-5508

This office provides the following information:

-Listing of areas available for lease

-Listing of past and present holders of State leases and a record of royalties paid

-Copies of some geologic information from past exploration on State leases 


\section{Washington}

By William Phillips

The nonfuel mineral industry of Washington State produces gold, silver, small amounts of lead and zinc, and diverse industrial materials such as sand and gravel, dolomite, limestone, silica, olivine, clay, and diatomite. Most of the value derived from mineral commodities in Washington comes from the production of magnesium metal from dolomite, precious metals, and sand and gravel.

Many gold deposits in Washington are hosted in or associated with nonmarine volcanic and sedimentary rocks of Eocene age (see "Geologic Time Chart" at end of report) in the northeast and central portions of the State near Republic and Wenatchee (see fig. 13). Exploration for new gold deposits in similar environments is being conducted by numerous companies. The origin, stratigraphic, and structural setting of these epithermal gold deposits are also the subjects of intensive studies. Geoscientists from the U.S. Geological Survey, Washington Department of Natural Resources, University of Washington, and Washington State University have produced many reports and maps documenting aspects of gold mineralization in the Eocene basin setting.

The populous Puget Lowlands on the west side of Washington State contain abundant sand and gravel resources of glacial origin that are widely mined. Similar resources in the mostly rural northeast portion of the State have not been extensively mined because of the distance between deposits and urban markets.

Dolomite is produced from Paleozoic metasedimentary rocks in northeast Washington near Addy. The dolomite is used to manufacture ferrosilicon as well as magnesium metal.

The Division of Geology and Earth Resources of the Washington Department of Natural Resources serves as a central repository of mineral and related geological information for Washington State. The Division maintains a research (nonlending) library containing virtually all published reports, maps, theses, dissertations, and abstracts pertaining to the geology of Washington State. In addition, the Division library has an excellent collection of unpublished, nonproprietary reports produced by consultants, and industry workers. The library is staffed by a reference librarian and supported by a computerized bibliographic information system. This system permits rapid

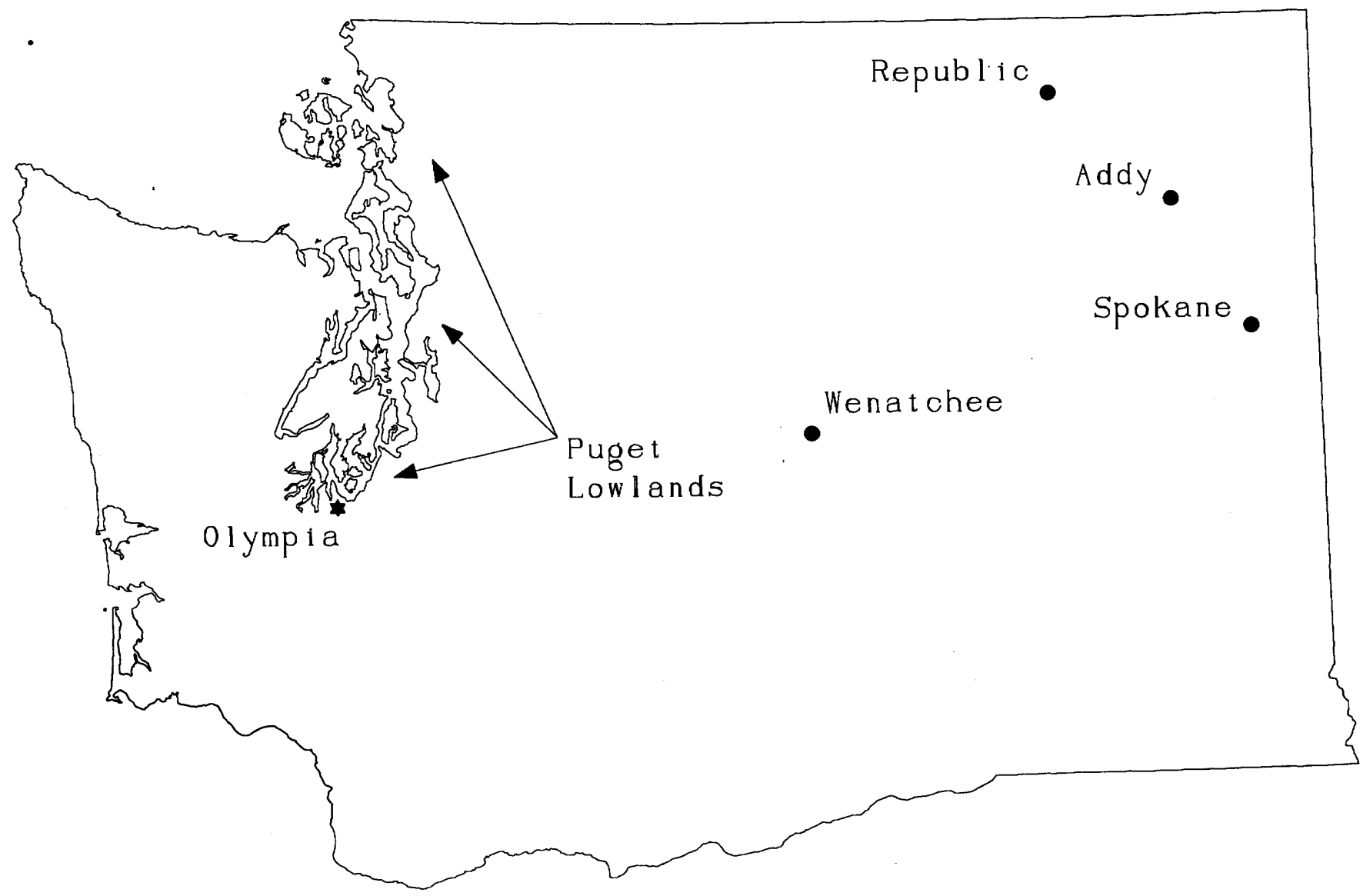

Figure 13. Index map of Washington, with sites referred to in text. 
and accurate searching of the thousands of references related to Washington geology. Comprehensive geological bibliographies are published on a regular basis by the Division and should be on the bookshelf of every geologist interested in Washington mineral resources.

A summary report describing the Washington mineral industry is published annually in the "Washington Geologic Newsletter." The report, which is based upon a questionnaire mailed to companies and individuals active in mineral exploration and development, briefly outlines production and exploration activity for metallic and many industrial mineral commodities. Sand and gravel deposits are not described in this annual report.

The Division of Geology and Earth Resources, the State's geological survey, is producing an updated 1:250,000-scale geologic map of the State in four quadrants. Each quadrant map is accompanied by supplemental information: map unit descriptions, correlation diagrams, source-of-data maps, and references cited are included on plates or in a pamphlet. Publication dates for the four quadrangles are: Southwest, 1987; Northeast, 1991; Southeast, 1993; Northwest, 1995.

Mineral assays and other analytical services are not provided by the Division of Geology and Earth Resources for the public. However, a free mineral identification service is available. The service consists of a simple megascopic examination of the sample by a geologist and does not include any chemical or $\mathrm{x}$-ray analyses.

Nonfuel surface mines in Washington State are regulated by the Division. Free information on the surface mine reclamation program is available at the Division's Olympia office. Exploration for nonfuel minerals is not regulated by State agencies in Washington. Companies are not required to submit copies of exploratory drill-hole logs or other data unless the work is performed on State land. Leases for prospecting or mining on State land are issued by the Division of Land and Minerals of the Washington Department of Natural Resources.

Professional registration is not required to practice geology in Washington. No professional geological registration or certification program is offered by the State of Washington.

\section{Mineral Information Facts at a Glance- Washington}

General mineral resource inquiries and publication sales:

\section{Main Office}

Division of Geology and Earth Resources

Department of Natural Resources

Mail Stop PY-12, Olympia, WA 98504

(206) 459-6372

FAX (206)459-6380

Office hours: 8:00 a.m. to 4:30 p.m.-Monday through Friday

\section{Field Office}

Division of Geology and Earth Resources

Department of Natural Resources

Spokane County Agricultural Center

N. 222 Havana

Spokane, WA 99202

(509) 456-3255

Office hours: 8:00 a.m. to 4:30 p.m.-Monday through Friday (due to the small staff size, it is advisable to make an appointment before visiting the field office.)

Important mineral-related publications of the Washington Division of Geology (Note: Publications available from Olympia office only; cash and check or money order payable to Department of Natural Resources. Mail orders must be prepaid; add $\$ 1$ for shipping and handling of each mail order.):

- "Inventory of Washington Minerals, Part I. Nonmetallic Minerals," by G.M. Valentine. 1949. ( $\$ 3.00)$

-Inventory of Washington Minerals, Part II. Metallic Minerals," by M.T. Huntting. 1956. (out of print)

-"Metal mines of Washington-preliminary report," by N.L. Joseph and Raymond Lasmanis. 1990. (\$15.00)

-Bibliography and Index of the Geology and Mineral Resources of Washington, 1963-1980," by C. J. Manson and Debbie Burnetti. 1983. (\$4.75)

-Preliminary Bibliography and Index of Geology and Mineral Resources of Washington, 1981-May 1, 1986," by C. J. Manson, 1986. (\$13.50)

"Directory of Washington Mining Operations," compiled by U.S. Department of Labor, Mine Safety and Health Administration. 1987. (\$1.00)

Services provided by the Olympia office of the Division of Geology and Earth Resources:

\footnotetext{
- Free mineral or rock identification (no ore assays)

-Free quarterly newsletter ("Washington Geologic Newsletter")

-Free mineral samples to students (limit 1 per student)

-Free brochures on gems and minerals, gold mining, and other popular subjects

- Comprehensive reference library (library materials are not lent)

- Free publication list

-Sale of numerous publications produced by the Division of Geology and Earth Resources. U.S. Geological Survey geologic maps, reports, or topographic maps are not for sale, although they may be viewed in the reference library.

-Consultation with staff geologists

-Regulation of nonfuel surface mines
}

Services provided by other divisions of the Department of Natural Resources:

-Prospecting/mining permits for State land

Division of Lands and Minerals

Mail Stop LB-13

Olympia, WA 98504

(206) $586-6382$

-Aerial photos, orthophoto quadrangles, and U.S. Geological Survey topographic quadrangles 
Photo and Map Sales Unit

Division of Engineering

Mail Stop AW-11

1065 Capitol Way

Olympia, WA 98504

(206) $753-5338$

Related information and regulation provided by other State and Federal agencies:

-Ground water, surface water, air quality, and shoreline management

Department of Ecology

Mail Stop PV-11

Olympia, WA 98504

(206) $459-6000$

-Hydraulic project permits (for example, placer mining)

Department of Fisheries

Division of Habitat Management

115 General Administration Building

Olympia, WA 98504

(206) $753-6650$

Department of Wildlife

Division of Habitat Management

600 Capitol Way North

Olympia, WA 98501-1091

(206) $753-5897$
-Regulation of coal mining

U.S. Department of the Interior

Office of Surface Mining

Olympia Office

3773-C Martin Way, Suite 104

Olympia, WA 98506

(206) 753-9538

Industry and trade associations:

Northwest Mining Association

414 Peyton Building

Spokane, Washington 99201

(509) 624-1158

Note: The Northwest Mining Association sponsors an important mining convention the first week of December in Spokane, Wash., and also publishes a membership directory.

Washington Aggregate and Concrete Association 18000 Andover Park West, Suite 204

Tukwila, WA 98188

(206) $575-3665$ 


\section{Wyoming}

By Dan Hausel

Few States have the variety of mineral resources that are available in Wyoming. It is the world's largest producer of trona (sodium bicarbonate), used to manufacture glass, baking soda, and a variety of speciality chemicals. Its coal rasources are estimated at nearly a trillion tons, and other major commodities include oil, gas, iron, uranium, and bentonite. Wyoming also has significant resources of rare and strategic metals and minerals such as gem and industrial diamonds, gold, copper, platinum, palladium, titanium, tungsten, manganese, chromium, vanadium, and one of the largest low-grade rare earth and thorium deposits in the United States.

Rock hounds find Wyoming a paradise. The State mineral is jade and is as high in quality as any jade in the world. Some other lapidary and gemstone materials include agate, jasper, agatized fossils, petrified wood, onyx, garnet, terrazo, sapphire, aquamarine, and ruby.

The Geological Survey of Wyoming, located in Laramie on the University of Wyoming campus, is the State agency charged with mapping, sampling, identifying, and providing information on these resources and their geology. The Survey has seven divisions: Coal, Geologic Hazards, Industrial Minerals and Uranium, Metals and Precious Stones, Oil and Gas, Publications, and Stratigraphy.

The Survey maintains a Publications Sales Office which handles the Survey's own publications and openfile reports on the geology and mineral resources of Wyoming, U.S. Geological Survey topographic maps of Wyoming, and thesis maps. Information on minerals is also available from both of the two minerals divisions. These divisions maintain a library of archives, unpublished mineral and field reports, mine maps, geologic maps, assays and geochemical data, published reports, and theses on the State's geology and mineral resources. These files are available for examination during normal working hours.

\section{Mineral Information Facts at a Glance-Wyoming}

General mineral resource inquiries and publication sales:

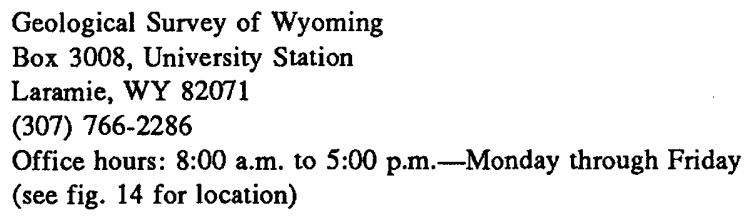

Formats Available:

Hard copies (nondigital). Free publication lists of formal and open-file reports available on request. Information contained in the Division's mineral files, that is, reports, theses, assays, mine maps, company reports, and so forth is available for free examination at the Survey offices. These files are available for photocopying by interested individuals.

Cost:

Formal publications, maps, and open files are available at minimal costs. Photocopies of most unpublished mineral reports can be provided at cost. Free pamphlets on (1) "Available Publications," (2) "Prospecting and Rock Hunting," (3) "Geologic History of Wyoming," and (4) "Minerals and Rocks of Wyoming" are available upon request.

Other Services:

The Geological Survey of Wyoming also offers a free rock and mineral identification service.

How to Order Information:

Telephone, write, or visit. 

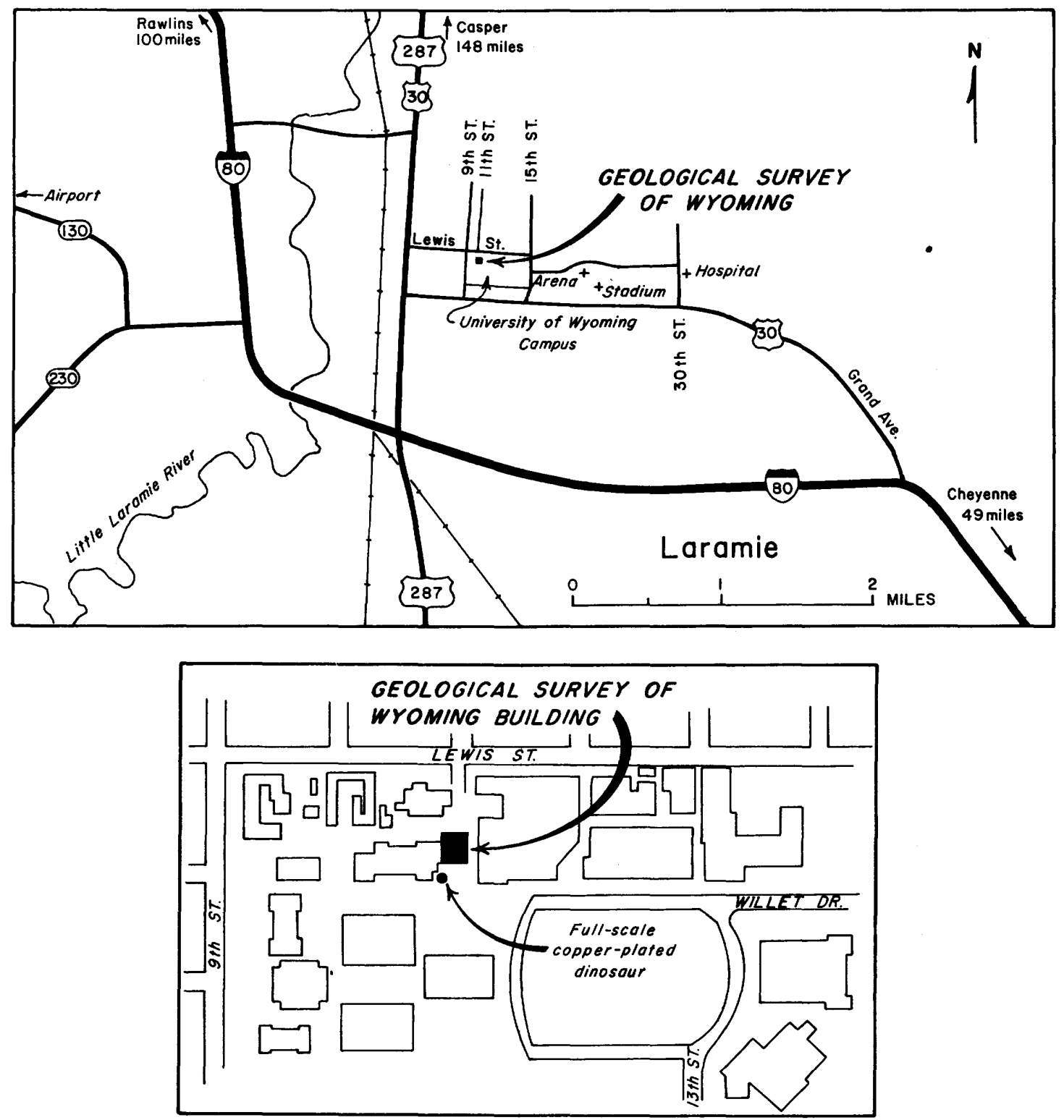

Figure 14. Location of Geological Survey of Wyoming, Laramie, Wyoming. 


\section{ADDITIONAL SOURCES OF MINERALS INFORMATION}

\section{Mining Associations and Geological Societies}

National, regional, and statewide nongovernmental organizations are sources of information about mineral resources. Mineral industry associations and geological societies hold lectures, workshops, field trips, and conferences. Some of these organizations also sell publications. Contact U.S. Geological Survey Minerals Information Offices, or the Minerals Information Institute discussed below, for more information about these groups.

\section{Educational Materials}

The Mineral Information Institute is a nonprofit organization that compiles and disseminates earth science information and helps educators develop geologic curricula. Most of the Institute's work is focused on elementary and secondary education. The Institute publishes a directory titled "Mineral Information Sources," that lists Federal and State agencies, as well as mineral industry associations, films, and popular publications about mineral resources. For more information, contact Mineral Information Institute, 1125 17th Street, Suite 1800, Denver, CO 80202, (303) 297-3226 
GEOLOGIC TIME CHART

Terms and boundary ages used by the U.S. Geological Survey in this report

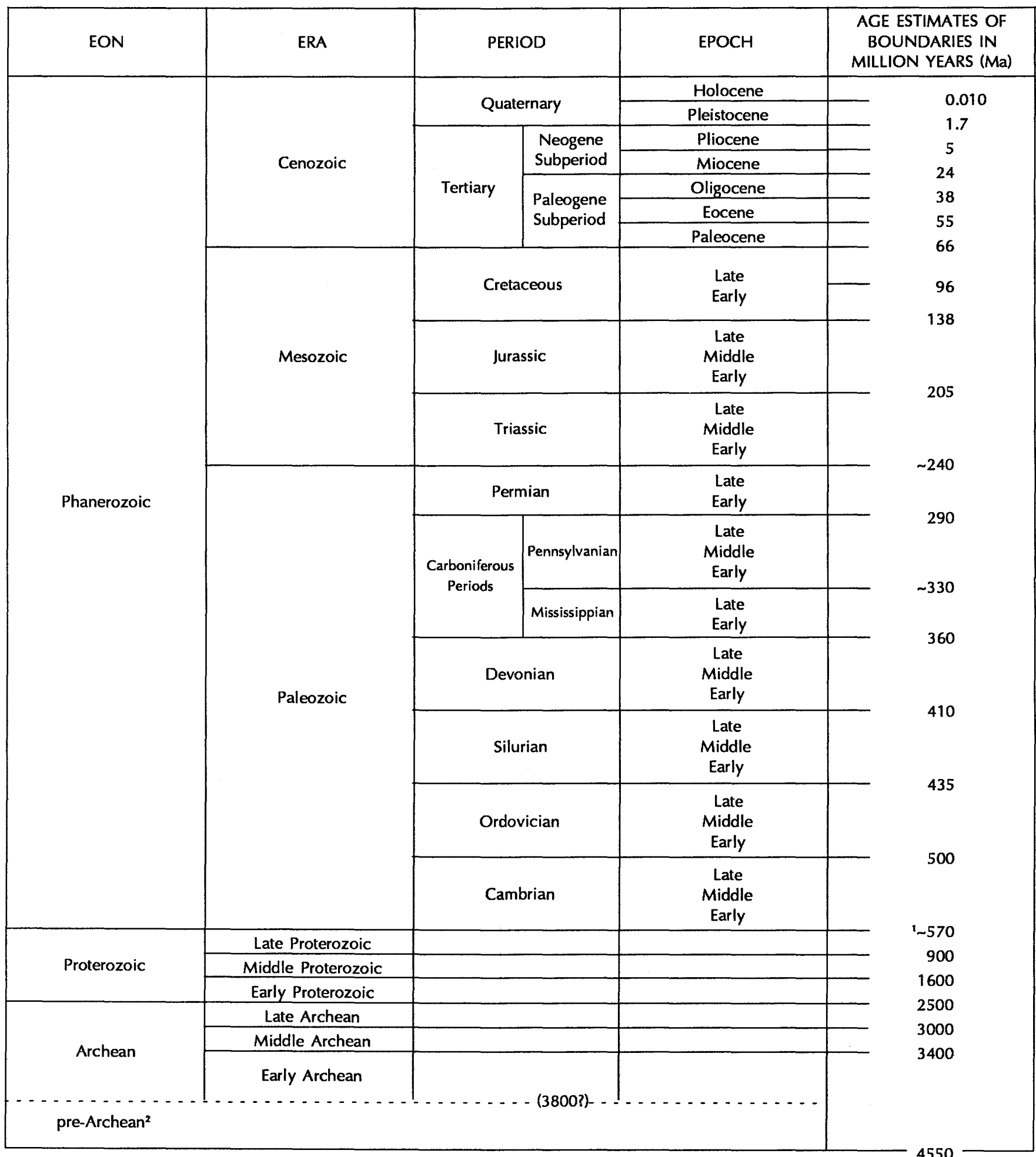

'Rocks older than $570 \mathrm{Ma}$ also called Precambrian, a time term without specific rank.

${ }^{2}$ Informal time term without specific rank. 
. 


$$
\text { - }
$$




\section{SELECTED SERIES OF U.S. GEOLOGICAL SURVEY PUBLICATIONS}

\section{Perlodicals}

Earthquakes \& Volcanoes (issued bimonthly).

Preliminary Determination of Epicenters (issued monthly).

\section{Technical Books and Reports}

Professional Papers are mainly comprehensive scientific reports of wide and lasting interest and importance to professional scientists and engineers. Included are reports on the results of resource studies and of topographic, hydrologic, and geologic investigations. They also include collections of related papers addressing different aspects of a single scientific topic.

Bulletins contain significant data and interpretations that are of lasting scientific interest but are generally more limited in scope or geographic coverage than Professional Papers. They include the results of resource studies and of geologic and topographic investigations; as well as collections of short papers related to a specific topic.

Water-Supply Papers are comprehensive reports that present significant interpretive results of hydrologic investigations of wide interest to professional geologists, hydrologists, and engineers. The series covers investigations in all phases of hydrology, including hydrogeology, availability of water, quality of water, and use of water.

Circulars present administrative information or important scientific information of wide popular interest in a format designed for distribution at no cost to the public. Information is usually of short-term interest.

Water-Resources Investigations Reports are papers of an interpretive nature made available to the public outside the formal USGS publications series. Copies are reproduced on request unlike formal USGS publications, and they are also available for public inspection at depositories indicated in USGS catalogs.

Open-File Reports include unpublished manuscript reports, maps, and other material that are made available for public consultation at depositories. They are a nonpermanent form of publication that may be cited in other publications as sources of information.

\section{Maps}

Geologic Quadrangle Maps are multicolor geologic maps on topographic bases in 71/2-or 15 -minute quadrangle formats (scales mainly $1: 24,000$ or $1: 62,500$ ) showing bedrock, surficial, or engineering geology. Maps generally include brief texts; some maps include structure and columnar sections only.

Geophysical Investigations Maps are on topographic or planimetric bases at various scales; they show results of surveys using geophysical techniques, such as gravity, magnetic, seismic, or radioactivity, which reflect subsurface structures that are of economic or geologic significance. Many maps include correlations with the geology.

Miscellaneous Investigations Series Maps are on planimetric or topographic bases of regular and irregular areas at various scales; they present a wide variety of format and subject matter. The series also includes 7 1/2-minute quadrangle photogeologic maps on planimetric bases which show geology as interpreted from aerial photographs. Series also includes maps of Mars and the Moon.
Coal Investigations Maps are geologic maps on topographic or planimetric bases at various scales showing bedrock or surficial geology, stratigraphy, and structural relations in certain coal-resource areas.

Oil and Gas Investigations Charts show stratigraphic information for certain oil and gas fields and other areas having petroleum potential.

Miscellaneous Field Studies Maps are multicolor or black-andwhite maps on topographic or planimetric bases on quadrangle or irregular areas at various scales. Pre-1971 maps show bedrock geology in relation to specific mining or mineral-deposit problems; post-1971 maps are primarily black-and-white maps on various subjects such as environmental studies or wildemess mineral investigations.

Hydrologic Investigations Atlases are multicolored or black-andwhite maps on topographic or planimetric bases presenting a wide range of geohydrologic data of both regular and irregular areas; principal scale is $1: 24,000$ and regional studies are at $1: 250,000$ scale or smaller.

\section{Catalogs}

Permanent catalogs, as well as some others, giving comprehensive listings of U.S. Geological Survey publications are available under the conditions indicated below from the U.S. Geological Survey, Books and Open-File Reports Section, Federal Center, Box 25425, Denver, CO 80225. (See latest Price and Availability List.)

"Publications of the Geological Survey, 1879-1961" may be purchased by mail and over the counter in paperback book form and as a set of microfiche.

"Publications of the Geological Survey, 1962-1970" may be purchased by mail and over the counter in paperback book form and as a set of microfiche.

"Publications of the U.S. Geological Survey, 1971- 1981" may be purchased by mail and over the counter in paperback book form (two volumes, publications listing and index) and as a set of microfiche.

Supplements for $1982,1983,1984,1985,1986$, and for subsequent years since the last permanent catalog may be purchased by mail and over the counter in paperback book form.

State catalogs, "List of U.S. Geological Survey Geologic and Water-Supply Reports and Maps For (State)," may be purchased by mail and over the counter in paperback booklet form only.

"Price and Availability List of U.S. Geological Survey Publicatons," issued annually, is available free of charge in paperback booklet form only.

Selected copies of a monthly catalog "New Publications of the U.S. Geological Survey" available free of charge by mail or may be obtained over the counter in paperback booklet form only. Those wishing a free subscription to the monthly catalog "New Publications of the U.S. Geological Survey" should write to the U.S. Geological Survey, 582 National Center, Reston, VA 22092.

Note.--Prices of Government publications listed in older catalogs, announcements, and publications may be incorrect. Therefore, the prices charged may differ from the prices in catalogs, announcements, and publications. 


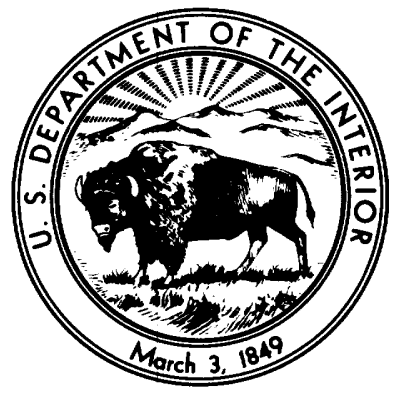

